\title{
Presence of mycotoxins in animal milk: a review
}

Myra Evelyn Flores-Flores ${ }^{a}$, Elena Lizarraga ${ }^{a}$, Adela Lopez de Cerain ${ }^{b}$, Elena González-Peñas $^{a *}$

${ }^{a}$ Department of Organic and Pharmaceutical Chemistry

${ }^{b}$ Department of Pharmacology and Toxicology

Faculty of Pharmacy, University of Navarra

Irunlarrea 1, 31008, Pamplona, Navarra, Spain

${ }^{*}$ Corresponding author. Elena González-Peñas. Tel.: +34 948 425653; fax: +34 948

425652. E-mail: mgpenas@unav.es

Myra Evelyn Flores-Flores (mflores.6@alumni.unav.es),

Elena Lizarraga (elizarraga@unav.es),

Adela López de Cerain (acerain@unav.es) 


\section{Abstract}

Mycotoxins can cause toxicity when ingested by humans and animals. Although the rumen is supposed to be a barrier against mycotoxins, some studies demonstrate that carry-over of mycotoxins to milk is possible. Different studies have found mycotoxin levels in animal milk, mainly related to contaminated feed for ruminants. Aflatoxin M1 is the most studied mycotoxin in milk and levels exceeding the EU maximum level for this mycotoxin in this matrix $(0.050 \mu \mathrm{g} / \mathrm{kg})$ have been found. Maximum levels in milk for other mycotoxins have not been established; however ochratoxin A, aflatoxins G1, G2, B1, B2 and M2, fumonisin B1, cyclopiazonic acid, zearalenone and its metabolites and deepoxydeoxynivalenol have also been found in milk samples. Taking into account that multi-exposure to mycotoxins is the most likely scenario and co-occurrence of mycotoxins could affect their toxicological effects in humans and animals, there is a need to determine the co-occurrence of mycotoxins in milk.

\section{Keywords}

Mycotoxin, cow milk, milk, ochratoxin $A$, aflatoxin M1, human exposure 


\section{Introduction ${ }^{1}$}

Mycotoxins are secondary metabolites produced by filamentous fungi that cause a toxic response when ingested by humans and animals. Fusarium, Aspergillus and Penicillium are the most abundant molds that produce mycotoxins and contaminate human foods and animal feeds through fungal growth prior to and during harvest or during improper storage (Binder, 2007).

Human exposure to mycotoxins occurs directly through the intake of contaminated agricultural products (cereals, corn, fruits, etc.) or indirectly through the consumption of products of animal origin (milk, eggs, etc.) prepared or obtained from animals that were fed with contaminated material (Capriotti, Caruso, Cavaliere, Foglia, Samperi \& Lagana, 2012).

\footnotetext{
${ }^{1}$ Abbreviations Used: 3-acetyldeoxynivalenol (3-ADON), 15-acetyldeoxynivalenol (15ADON), aflatoxin B1 (AFB1), aflatoxin M1 (AFM1), aflatoxin M2 (AFM2), cyclopiazonic acid (CPA), deoxynivalenol (DON), deepoxy-deoxynivalenol (DOM-1), diacetoxyscirpenol (DAS), fumonisin B1 (FB1), fusarenon X (FUS-X), neosolaniol (NEO), nivalenol (NIV), ochratoxin A (OTA), ochratoxin B (OTB), patulin (PAT), sterigmatocystin (STC), toxin T-2 (T-2), toxin HT-2 (HT-2), zearalenone (ZEA), zearalanone (ZAN), $\alpha$-zearalanol ( $\alpha-Z A L), \beta$-zearalanol ( $\beta$-ZAL), $\alpha$-zearalenol ( $\alpha-Z E L)$, $\beta$-zearalenol ( $\beta$-ZEL), International Agency for Research on Cancer (IARC), Joint FAO/WHO Expert Committee on Food Additives (JECFA), European Food Safety Authority (EFSA), Provisional Maximum Tolerable Daily Intake (PMTDI), Tolerably Daily Intake (TDI), Limit of Detection (LOD), Limit of Quantification (LOQ).
} 
Many human diseases are related with intake of mycotoxins, especially chronic consumption, with the main toxic effects being carcinogenicity, genotoxicity, hepatotoxicity, nephrotoxicity, oestrogenicity, reproductive disorders, immunosuppression and dermal irritation (Anfossi, Baggiani, Giovannoli \& Giraudi, 2010). The well-documented presence of some mycotoxins in feed and food has led the European Union to establish maximum limits (MLs) for certain mycotoxins in food for human (European Commission, 2007; 2010a; 2010b) and animal consumption (European Commission, 2003; 2006).

Cow milk consumption is high because it is important in the diet of all age groups. It provides a number of important nutrients that are essential for humans. Children are the largest consumers of milk as it is one of the principal foods during their first years of life. Thus, it is very important that milk is free of toxic compounds that can be harmful for humans, but especially for children which are more susceptible to the action of toxic compounds.

Milk contamination and contamination of mycotoxins in animals are not only a human health concern, but they also cause economic losses to farmers due to mycotoxin adverse effects that cause poor animal productivity (Bryden, 2012).

Mycotoxin presence in material intended for animal feed and some studies showing the presence of mycotoxins in dairy cow plasma (Winkler, Kersten, Meyer, Engelhardt \& Dänicke, 2014) raise the possibility that these toxins could be carried over into the cow milk. Rumen flora is supposed to be a defense against mycotoxins due to the fact that some of them: ochratoxin A (OTA), deoxynivalenol (DON), aflatoxin B1 (AFB1) and zearalenone (ZEA) are metabolized to less toxic compounds. However, other mycotoxins, such as patulin (PAT) or fumonisins, pass the rumen barrier unchanged (Fink-Gremmels, 2008). Moreover, the rumen barrier can be altered by animal diseases, 
changes in the diet or high mycotoxin contamination in the animal feed (Pattono, Gallo \& Civera, 2011).

It is very important to study the presence of xenobiotics in foods, and consequently in milk, in order to provide data regarding human exposure and so as to be able to evaluate the human health risks associated with the ingestion of low doses of these toxic compounds over long periods of time. Moreover, co-occurrence of mycotoxins in feed and food are likely, and the influence of their simultaneous presence in their toxicological effects should be studied.

Regulation of the maximum presence of mycotoxins in milk and milk products is generally limited for aflatoxin M1 (Table 1). With respect to other mycotoxins, only Slovakia has established $5 \mu \mathrm{g} / \mathrm{kg}$ as maximum limit for Aflatoxin B1, Ochratoxin A, Sterigmatocystin and $50 \mu \mathrm{g} / \mathrm{kg}$ for Patulin; Czech Republic has set $5 \mu \mathrm{g} / \mathrm{kg}$ for Sterigmatocystin.

The aim of this work is to review the research work carried out regarding the potential presence of mycotoxins in milk, presenting a summary of the state-of-the-art on this topic.

\section{Fumonisins}

Fumonisins are synthesized mainly by Fusarium verticillioides (syn. Fusarium moniliforme) and Fusarium proliferatum. However, other fungal species including Fusarium napiforme, Fusarium dlamini and Fusarium nygamai are also able to produce fumonisins. In animals, some studies have evidenced that FB1 intake led to a decreased milk production and feed intake (Richard et al., 1996; Whitlow, Diaz, Hopkins \& Hagler, 2006; Fink-Gremmels, 2008). Also, fumonisins provoke pulmonary edema, hepatic fibrosis and leukoencephalomalacia or liver disease. 
Fumonisin B1 (FB1) has been classified as a 2B carcinogen (possibly carcinogenic to humans) by the International Agency for Research on Cancer (IARC). The European commission has recommended a provisional maximum tolerable daily intake (PMTDI) for fumonisins B1, B2 and B3, alone or in combination, of $2 \mu \mathrm{g} / \mathrm{kg} \mathrm{b.w.} \mathrm{per} \mathrm{day.}$

In Vitro studies have concluded that FB1 is poorly metabolized in the rumen (Caloni, Spotti, Auerbach, Op den Camp, Gremmels \& Pompa, 2000), and therefore, it could reach the milk. At least 2 studies have found natural contamination of FB1 in milk samples for human consumption (Table 2). Maragos \& Richard (1994) have reported FB1 in 1 out of 155 analyzed samples, at a concentration of $1290 \mathrm{ng} / \mathrm{L}$; whereas in a more recent study (Gazzotti, Lugoboni, Zironi, Barbarossa, Serraino \& Pagliuca, 2009) it has been reported FB1 in 8 out of 10 tested milk samples, with a maximum level of 430 $\mathrm{ng} / \mathrm{kg}$ and an average in accordance with the value predicted by the Monte Carlo exposure assessment model developed by Coffey, Cummins \& Ward (2009) (predicted mean level $=360 \mathrm{ng} / \mathrm{kg}$ ). Even when considering the bigger FB1 level encountered in milk (1 $290 \mathrm{ng} / \mathrm{L}$ ), it appears to be unlikely that the proposed PMTDI is surpassed, but more research work regarding FB1 contamination in milk, analyzing a large number of samples, would be recommended.

\section{Cyclopiazonic acid}

The cyclopiazonic acid (CPA) is a potent neurotoxin produced by Penicillium and Aspergillus. Surveys regarding the presence of CPA in different foods, including milk, are scarce. However, molds producing this toxin are widespread in different food commodities, thus further studies on its occurrence are needed. Two studies, carried out in Italy (Losito, Monaci, Aresta \& Zambonin, 2002) and Brazil (Oliveira, Rosmaninho \& Rosim, 2006a) have found milk samples contaminated with CPA in levels up to 9700 ng/L (Table 2) when only 48 samples were analyzed. 


\section{Zearalenone}

Zearalenone (ZEA) is a non-steroidal mycotoxin produced by Fusarium cerealis, Fusarium culmorum, Fusarium equiseti, Fusarium graminearum and Fusarium pallidoroseum. Zearalenone and its metabolites zearalanone (ZAN), $\alpha$-zearalanol ( $\alpha$ ZAL), $\beta$-zearalanol ( $\beta$-ZAL), $\alpha$-zearalenol ( $\alpha$-ZEL) and $\beta$-zearalenol ( $\beta$-ZEL) are capable of binding the estrogen receptor and therefore, they could lead to problems in the mammalian reproductive system (Le Guevel \& Pakdel, 2001). Moreover, a-ZAL had been widely used for increasing the rate of body weight gain and improving feed conversion in ruminants.

Due to their usage, considerable attention has been paid to the potential human health risk. Thus, in 1996, the Council Directive 96/23/EC included these resorcylic acid lactones in Group A (substances having anabolic effect and unauthorized substances), and they were banned within the EU in order to protect consumer health.

Due to their toxic effects, the Joint FAO/WHO Expert Committee on Food Additives (JECFA) has recommended a PMTDI of $0.5 \mu \mathrm{g} / \mathrm{kg}$ b.w. for ZEA and metabolites.

Levels of ZEA, ZAN and $\alpha-Z A L$ of up to $12.5 \mu \mathrm{g} / \mathrm{kg}$, have been detected after analysis of approximately 400 milk samples from Hungary, Egypt, UK and China. For details, see Table 2. In the worst case scenario (12.5 $\mu \mathrm{g} / \mathrm{kg}$ of ZEA) (El-Hoshy, 1999), an adult (50$70 \mathrm{~kg}$ ) should drink $2-2.8 \mathrm{~L}$ of milk daily to reach the PMTDI. Therefore, human exposure to ZEA from milk is not considered to be a health risk. However, toxicity from ZEA metabolites should be taken into consideration; for instance, $\alpha-Z E L$ is 3 times more estrogenic than ZEA (Mirocha, Pathre \& Robison, 1981). This compound has been found in milk samples in China in levels up to $73.5 \mathrm{ng} / \mathrm{kg}$ (Huang et al., 2014). 


\section{Sterigmatocystin}

Sterigmatocystin (STC) is produced by many Aspergillus species, with Aspergillus versicolor being the main STC producer. It was classified as a 2B carcinogen by the IARC. STC is of interest because of its structural relationship to aflatoxin B1, being a precursor in aflatoxin biosynthesis.

Although STC has frequently been detected in different foodstuffs, there is no summarized information about its occurrence and analysis in food. There is no European Union legislation for STC and therefore, no official control and monitoring programs. There are some papers (Versilovskis, Van Peteghem \& De Saeger, 2009; Versilovskis \& De Saeger, 2010) that report the presence of STC in cheese. Some of them point out indirect contamination which results from lactating animals ingesting contaminated feed. Regarding to this assumption, some studies have found STC in essential components of the milking cow diet like hay (Buckle, 1983) and corn (Tian \& Liu, 2004).

\section{Trichothecenes}

Produced particularly by molds belonging to the genus Fusarium, trichothecene mycotoxins are the largest group of toxins, and they are ubiquitous in moderate climate areas. Approximately 170 trichothecene mycotoxins have been discovered so far. They are divided into different groups according to their characteristic functional groups: Type A, including diacetoxyscirpenol (DAS), neosolaniol (NEO) and the highly toxic HT-2 and T-2 toxins, and Type B, including deoxynivalenol (DON, vomitoxin), 3acetyldeoxynivalenol (3-ADON), 15-acetyldeoxynivalenol (15-ADON), nivalenol (NIV) and fusarenon X (FUS-X). With regard to their toxic effects, trichothecenes type $A$ causes vomiting, diarrhea, leukopenia, necrotic lesions and hemorrhage while 
trichothecenes type B causes food refusal and vomiting, kidney problems and immunosuppression (Capriotti et al., 2012). The European Commission has recommended a PMTDI of $60 \mathrm{ng} / \mathrm{kg}$ b.w. for T-2 and HT-2 toxins, alone or in combination and $1 \mu \mathrm{g} / \mathrm{kg}$ b.w. for DON.

In milk, DON has been studied along with its metabolite DOM-1. Sørensen and Elbæk (2005) have found up to $0.3 \mathrm{ng}$ DOM-1/mL in 5 out of 20 milk samples collected in Denmark (Table 2).

\section{Patulin}

Patulin is a mycotoxin produced by certain species of the genera Aspergillus and Penicillium, including Aspergillus clavatus, Penicillium expansum, Penicillium patulum, Penicillium aspergillus and Penicillium byssochlamys. Exposure to this mycotoxin is associated with neurological, immunological, carcinogenic, teratogenic, genotoxic, and gastrointestinal outcomes (Capriotti et al., 2012; Puel, Galtier \& Oswald, 2010). However, the mechanisms through which patulin causes toxicity are still not wellunderstood.

At the time of writing this manuscript, no studies reporting the occurrence of patulin in milk could be found. However, some studies reported the presence of fungi producers of this mycotoxin in cheese (Taniwaki, Silva, Banhe \& Lamanaka, 2001). Cheese could be contaminated indirectly, through contaminated milk, or directly, when fungal contamination appears. Regarding to this assumption, at least one study has found PAT in an essential component of the milking cow diet like grass silage (Buckle, 1983).

\section{Ochratoxins}

Among them, the most important ochratoxin, due to its prevalence in foods and toxicity is ochratoxin A. It is a stable compound that is not destroyed by common food 
preparation procedures. Temperatures above $250^{\circ} \mathrm{C}$ for several minutes are required in order to reduce the toxin concentration (Boudra, Le Bars \& Le Bars, 1995). Ochratoxin $B(O T B)$ is a dechloro analog of OTA. Ochratoxins $A$ and $B$ are produced by several fungal species in the Penicillium and Aspergillus genera, primarily Penicillium verrucosum, Aspergillus ochraceus, Aspergillus melleus, and Aspergillus petrakii, among others. Exposure to OTA has been associated with distinct endemic renal diseases in the Balkans, referred to as Balkan Endemic Nephropathy (BEN) and Urinary Tract Tumors (UTT). The IARC classified it as being possibly carcinogenic to humans (2B group). Thus, the European Commission has recommended a Provisional Tolerable Weekly Intake (PTWI) of 120 ng/kg b.w. for OTA.

Although OTB may have co-existed in some of the naturally contaminated materials tested for toxicity in animal studies, the concentrations are generally low and this mycotoxin appears to be much less toxic than OTA (Mally et al., 2005).

OTA concentrations found in the 505 analyzed samples of bovine milk were low. Studies carried out in Italy, Sweden, Norway, France and China found OTA at levels in the range of 5-84.1 ng/L, low enough to be considered that the PTWI could not be reached in an adult. However, some exceptions may occur if cows are ingesting large amounts of OTA (González-Osnaya, Soriano, Moltó \& Mañes, 2008). In addition, sudden changes in feed composition or the inclusion of a high percentage of proteinrich concentrates in the diet may alter the capability of rumen microorganisms to degrade OTA (Skaug, 1999; Fink-Gremmels, 2008). In Sudan, a sample contaminated at $2730 \mathrm{ng} / \mathrm{L}$ has been found (Table 2).

Even though only low concentrations of OTA may be present in milk, these small amounts may be important to consumers of large quantities of this product, particularly children. Skaug (1999) has found that small children who consume large quantities of 
milk may have a total daily intake of OTA which is greater than the Tolerably Daily Intake (TDI) of $5 \mathrm{ng} / \mathrm{kg} \mathrm{b.w./day.} \mathrm{Moreover,} \mathrm{other} \mathrm{ochratoxin} \mathrm{sources} \mathrm{could} \mathrm{be} \mathrm{in} \mathrm{the} \mathrm{diet}$ of children. However, the European Commission has not established regulations for OTA contamination of milk and dairy products.

\section{Aflatoxins}

Aflatoxins (AFs) are toxic metabolites produced by the molds Aspergillus flavus, Aspergillus parasiticus and Aspergillus nomius which grow especially in areas with hot, humid climates and they can be found in several types of foods destined for both human and animal consumption. From a chemical standpoint, aflatoxins belong to the difuranocoumarin group.

Among AFs (B1, B2, G1 and G2), AFB1 is the most commonly found in food. It is highly toxic, in terms of both acute and chronic toxicity, and it is classified by the IARC as a human carcinogen (group 1).

Exposure to aflatoxins is typically through the ingestion of contaminated foodstuff, while dermal exposure results in slow and insignificant absorption. Aflatoxins are most commonly known for causing acute or chronic liver disease, but they are also considered immunosuppressive, hepatotoxic, mutagenic, teratogenic, and carcinogenic. In animals, exposure to aflatoxins results in impairment of liver function and reduced food intake, which might also explain the reduced milk production in dairy cattle exposed to aflatoxins (Fink-Gremmels, 2008).

A small number of studies on AFs in milk -apart from aflatoxin M1 (AFM1)- has been published and they report 112 analyzed milk samples. Herzallah (2009) has reported levels of AFB1, AFB2, AFG1, AFG2 and aflatoxin M2 (AFM2) in Jordan and Nakajima et al. (2004) have reported levels of AFM2 in Japan (See details in Table 2). 
Most of the studies regarding mycotoxin presence in milk are focused on AFM1 analysis. It is the main hydroxylated aflatoxin metabolite in milk from dairy cows that have consumed foodstuffs containing AFB1. Stoloff (1997) and Battacone et al. (2003) have reported that AFM1 can be found in animal milk within 12-24h after the first ingestion of AFB1 and can last up to 3 days after the last ingestion of the mycotoxin. In humans, it is also present in milk from nursing mothers who consumed a diet contaminated with AFB1 (Navas, Sabino \& Rodriguez-Amaya, 2005).

The presence of AFM1 in animal milk has been reported in several studies (Tables 3 6) worldwide. From 22189 milk samples analyzed for AFM1 contamination that were taken into account in this review, at least $9.8 \%$ of them (2 190 samples) from all around the world exceeded the ML established by EU $(0.05 \mu \mathrm{g} / \mathrm{kg})$. This percentage of samples could be higher because many studies report only the number of samples exceeding the US regulation for AFM1 $(0.5 \mu \mathrm{g} / \mathrm{kg})(\mathrm{FDA}, 2005)$, which is higher than in European regulations.

In regard to the geographic distribution of the total number of samples, the reference literature showed that the largest number of samples tested came from the continent of Europe (61.1\%) (Table 3), and the smallest number of samples assayed came from Africa (Table 4), contributing $4.4 \%$ of the total number of samples. In this survey, Turkey has been considered part of Asia.

In regard to the number of samples by continent exceeding the $\mathrm{ML}$ set by the $\mathrm{EU}$, at least 1709 were from Asia (7.7\% of total samples and $26.8 \%$ of Asian samples) (Table 5), 253 from Africa ( $1.1 \%$ of total samples and $25.8 \%$ of African samples) (Table 4), 119 from Europe ( $0.5 \%$ of total samples and $0.9 \%$ of European samples) (Table 3), and 109 from America ( $0.5 \%$ of total samples and $8.6 \% \%$ of American samples) (Table 6$)$. It can be observed that Asia accounts for the highest percentage of milk samples exceeding 
MLs, despite the fact that the total number of Asian samples accounts for only $28.7 \%$ of the total number of samples tested worldwide.

In regard to all the countries from where occurrence of AFM1 has been detected, milk samples from Egypt, Kenya, Libya, Morocco, Nigeria, Sudan, Argentina, Brazil, Colombia, Mexico, Trinidad, China, India, Iran, Jordan, Korea, Kuwait, Pakistan, Syria, Thailand, Turkey, Albania, Croatia, Italy, Greece and Portugal have reported levels exceeding the maximum allowed level in Europe. Milk samples from Austria, Cyprus, Finland, France, Germany, Ireland, Japan, Lebanon, Netherlands, Spain, Sweden and UK have presented AFM1 levels, but they do not reach the maximum established by EU.

The highest levels of AFM1 found in milk from each of the continents has been reported as follows: India (Asia) at levels of $48000 \mathrm{ng} / \mathrm{L}$ (Thirumala-Devi et al., 2002); Egypt (Africa), up to $8000 \mathrm{ng} / \mathrm{L}$ (El-Sayed, Neamat-Allah \& Soher, 2000); Brazil (America), up to $1000 \mathrm{ng} / \mathrm{L}$ (Oliveira, Germano, Bird \& Pinto, 1997); and in Europe, Albania recorded the highest levels, reaching $850 \mathrm{ng} / \mathrm{kg}$ (Panariti, 2001).

In fact, over the past 5 years, at least Sudan (Elzupir \& Elhussein, 2010), Iran (Fallah, 2010a), Pakistan (Iqbal, Asi \& Jinap, 2013), China (Zhang et al., 2012) and Brazil (Iha, Barbosa, Okada \& Trucksess, 2013) have found high AFM1 levels (510 - $6900 \mathrm{ng} / \mathrm{L})$ that exceed not only EU legislation but also U.S. maximum limits.

With respect to the type and origin of milk samples, the presence of AFM1 has been studied in milk samples from cows and other species such as sheep, goats and buffalos. Concentrations of AFM1 were found to be above the European Limit in at least one sample of each type of milk (Tables $3-6$ ).

\subsection{Influence of type of Feeding}


At least 8 studies coincide in that milk from animals fed by grazing present lower levels of AFM1 in comparison with milk from animals fed with compound feed and/or stored foodstuff. Panariti (2001) found relatively higher levels of AFM1 when cows have a diet composed mainly of stored feedstuffs rather than when the cows were at pasture (Table 3). Another study (Diaz \& Espitia, 2006) reports that batches of contaminated milk were produced at farms using feed supplements such as corn by-products or cottonseed meal, as opposed to farms where the cows were only grazing and did not received supplemental feeds (Table 6). Thirumala-Devi et al. (2002) analyzed milk from rural and peri-urban areas in India and found that most of the milk samples that contained high AFM1 concentrations were obtained from peri-urban areas where cows were fed with cotton cake, groundnut cake, rice bran and straw. A study published for Bognano et al. (2006) revealed that the contamination of samples obtained from stabulated ewes fedwith compound feed was higher than that from grazing ewes. Four studies (Ghanem \& Orfi, 2009; Hassan \& Kassaify, 2014; Rahimi, Bonyadian, Rafei \& Kazemeini, 2010; Srivastava, Bu-Abbas, Alaa-Basuny, Al-Johar, Al-Mufti \& Siddiqui, 2001) found a high level of AFM1 in cow milk compared with that from other animals (e.g. water buffalos, camels, sheep and goats). All these authors postulate that these low levels could be related to the fact that these species are mainly fed by grazing.

\subsection{Seasonal changes in AFM1 concentrations in milk}

It is known that hot and humid climates are favorable to the growing of aflatoxinproducing fungus but nevertheless, not all studies are in agreement regarding seasonal influence. Blanco et al. (1988) and El Marnissi et al. (2012) found high contamination in milk samples collected in autumn; Diaz \& Espitia (2006) found the highest AFM1 concentration predominantly in the rainy season; Markaki \& Melissari (1997) and Rodriguez, Calonge \& Ordonez (2003) reported no seasonal influence on the aflatoxin 
content in the milk samples they analyzed. Panariti (2001), Tajkarimi et al. (2007; 2008), Hussain \& Anwar (2008), Ozsunar, Gumus, Arici \& Demirci (2010), Nemati, Mehran, Hamed \& Masoud (2010), Heshmati \& Milani (2010), Ruangwises \& Ruangwises (2010) and Iqbal, Asi \& Jinap (2013) have found higher AFM1 concentrations in winter compared with other seasons. Most of the authors presumed that the marked higher contamination of AFB1 in foodstuffs during winter could be a result of the feed, consisting mainly of stored foodstuff, sometimes keep under humid conditions and thereby facilitating the growth of fungi and accumulation of toxins. Future studies must record weather conditions (temperature, humidity, rainfall, etc.) and stored conditions that could help clarify the apparent discrepancies of the current studies.

\subsection{Effects of processing}

The presence of AFM1 has been studied in raw, pasteurized, powder, organic, concentrated and ultra-high temperature treated (UHT) milk samples. At least one study in each type of milk found concentrations of AFM1 above the European Limit (Tables 3 6). Studies regarding the effects of heat processing on the amount of AFM1 in dairy products are ambiguous, but most of them indicate that treatments such as pasteurization and sterilization do not cause an appreciable change in the concentration of AFM1 in the product. With respect to other processes applied to milk, with or without heating, such as evaporation, concentration or drying, large losses of AFM1 were reported in some studies, whereas in other studies, they did not affect the AFM1 content (Prandini, Tansini, Sigolo, Filippi, Laporta \& Piva, 2009). 


\section{Mycotoxin carry-over into the milk}

Although the rumen is supposed to be a barrier against mycotoxin contamination, the analysis of milk samples demonstrates that the carry-over of mycotoxins into the milk is possible in some cases.

Few works have studied the possibility of the carry-over of fumonisins from feed into milk, and the results obtained were contradictory. Scott, Delgado, Prelusky, Trenholm \& Miller (1994), Richard et al. (1996) and Prelusky et al. (1996) did not detect fumonisins in milk after oral administration of up to $5 \mathrm{mg} \mathrm{FB} 1 / \mathrm{kg} \mathrm{b.w.} \mathrm{(even} \mathrm{when} \mathrm{a} 3 \mathrm{mg} \mathrm{FB} 1 / \mathrm{kg}$ b.w. dose was administered daily for 14 days).

Spotti, Caloni, Fracciolla, Pompa, Vigo \& Maffeo (2001) demonstrated that fumonisins are able to pass through the mammary barrier into the milk when FB1 is perfused into the blood of the udder. Scott et al. (1994) and Prelusky et al. (1996) did not detect fumonisins in milk after intravenous administration of up to $0.2 \mathrm{mg} \mathrm{FB} 1 / \mathrm{kg} \mathrm{b.w}$. On the other hand, Hammer, Blüthgen \& Walte (1996) detected FB1 after intravenous administration of approximately $0.046-0.067 \mathrm{mg} \mathrm{FB} 1 / \mathrm{kg} \mathrm{b.w}$. According to European Food Safety Authority (EFSA) (2005), the carry-over of fumonisins into milk is limited and does not significantly contribute to total human exposure. Dorner, Cole, Erlington, Suksupath, McDowell \& Bryden (1994) administered CPA to 3 lactating ewes at a rate of $5 \mathrm{mg} / \mathrm{kg} \mathrm{b.w}$. per day and found levels of CPA in milk which were $236 \mathrm{ng} / \mathrm{g}$ (the day after the first dose) and $568 \mathrm{ng} / \mathrm{g}$ (the day following the second dose). After 2 days, dosing of CPA was discontinued because of marked and rapid toxic effects in the ewes. Milk production at $48 \mathrm{~h}$ was only $20 \%$ of the expected and feed intake dropped substantially. 
According to the EFSA scientific opinion in 2004, ZEA has a limited tissue deposition and a low transmission rate into milk (EFSA, 2004a). Some transmission experiments in which cows were administered low levels of ZEA $(0.5-165 \mathrm{mg}$ daily, $0.77-340 \mu \mathrm{g} / \mathrm{kg}$ b.w.) detected no ZEA or metabolites in milk (Shreeve, Patterson \& Roberts, 1979; Prelusky, Scott, Trenholm \& Lawrence, 1990; Goll, Valenta \& Oldenburg, 1995). In the study of Prelusky and others, a dose of 544.5 mg ZEA (approx. $940-1130 \mu \mathrm{g}$ ZEA/kg b.w.) during 21 days had to be applied in order to observe transmission of ZEA and metabolites into milk (2.5 ng ZEA/mL, $3 \mathrm{ng}$ a-ZEL/mL). In another study, the maximum detected ZEA levels in the milk of cows fed daily with 25-100 mg ZEA (55.6 - 222.2 $\mu \mathrm{g} / \mathrm{kg}$ b.w.), during 6 days, were 0.39 and $1.16 \mathrm{ng} / \mathrm{mL}$ (Usleber, Renz, Martlbauer \& Terplan, 1992). These authors concluded that the ZEA level of contamination is low, even after high oral ZEA doses. However, Mirocha and others found a high level of ZEA and metabolites of $1359 \mathrm{ng} / \mathrm{mL}$ seven days after starting a daily dose of $200 \mathrm{mg} Z \mathrm{ZEA}$.

Although the study of Hagler, Danko, Horvath, Palyusik \& Mirocha (1980) showed low levels of ZEA and metabolites transmitted into the ewe milk, they were enough to cause strogenic effects in its offspring. The ewe used in the experiment had a 1-week-old female lamb which received all the milk not used for analysis. Within 10 days after administration of ZEA to the ewe, the lamb showed signs of hyperestrogenic syndrome. Transmission studies regarding trichothecenes have been carried out only with DON, NIV, FUS-X and T-2.

Studies performed on cows conclude that DON is very rapidly biotransformed to deepoxy-deoxynivalenol (DOM-1) in the rumen (Côté, Dahlem, Yoshizawa, Swanson \& Buck, 1986; Seeling et al., 2006; Keese et al., 2008) and unmetabolized DON is excreted at an extremely low rate into the milk $(0.0001 \%$ of the dose, $1-3 \mathrm{ng} \mathrm{DON} / \mathrm{mL})$ (Prelusky, Trenholm, Lawrence \& Scott, 1984). Levels of up to $26 \mathrm{ng}$ DOM-1/mL have 
been detected in cow milk by Côté et al. (1986) when 2933 - 5867 ug DON/kg b.w. was administered daily. One study carried out on ewes, and with higher doses of DON administered (16 $500-18860 \mu \mathrm{g}$ DON/kg b.w), reported levels of up to $17 \mathrm{ng} \mathrm{DON} / \mathrm{mL}$ and $205 \mathrm{ng}$ DOM-1/mL when DON was orally administered, but with a lower and intravenously single dose of DON (4000 $\mu \mathrm{g}$ DON/kg b.w.), the levels in milk reached up to $61 \mathrm{ng}$ of DON/mL and $1220 \mathrm{ng}$ of DOM-1/mL (Prelusky, Veira, Trenholm \& Foster, 1987).

Poapolathep, Sugita, Phitsanu, Doi \& Kumagai (2004) have performed transmission studies of NIV and FUS-X in mice and also their distribution in whey, fat and casein acid into mouse milk. They concluded that NIV is transmitted to milk without metabolization, and FUS-X is metabolized and transmitted mainly as NIV.

A study determined that $0.2 \%$ of the T-2 dose given to one Jersey cow was transmitted into the milk in the form of T-2, HT-2, NEO, 4-deacetylneosolaniol along with 4 more unknown metabolites, 3 of which accounted for $60-70 \%$ of the total T-2 and metabolites excreted (Yoshizawa, Mirocha, Behrens \& Swanson, 1981).

Although bio-transfer of OTA into milk has been demonstrated in other animal species (Breitholtz-Emanuelsson, Palminger-Hallén, Wohlin, Oskarsson, Hult \& Olsen, 1993; Ferrufino-Guardia, Tangni, Larondelle \& Ponchaut, 2000), in ruminants, the resident microflora of the rumen decreases bioavailability through hydrolysis of OTA to its metabolite ochratoxin a (OTa) (Skaug, 1999). Only 2 transmission studies on cows have been carried out. Shreeve and others (1979) could not detect OTA or OTa in milk after feeding 2 milking cows with levels of up to $25 \mu \mathrm{g}$ OTA/kg b.w. daily for 11 weeks.A higher dose (13 300 g OTA/kg b.w) administered by Ribelin, Fukushima \& Still (1978) produced $650 \mathrm{mg}$ of OTA and $4500 \mathrm{mg}$ of OTa in the milk measured the day after administration. 
There are five studies where levels of up to $200 \mu \mathrm{g}$ of AFB1 or AFB1 and OTA or ZEA were administered daily to cows (Shreeve et al., 1979; Veldman, Meijs, Borggreve \& Heeres-van, 1992; Masoero, Gallo, Moschini, Piva \& Diaz, 2007; Pietri, Bertuzzi, Piva, Binder, Schatzmayr \& Rodrigues, 2009; Britzi et al., 2013) and they showed that AFM1 appears in milk after AFB1 administration. Inasmuch as AFB1 carry-over into the milk in the form of AFM1 is very well known, most studies have been focused on different factors that can influence AFM1 transmission. The carry-over of AFB1 (excreted as AFM1) into cow milk appears to be influenced by the lactation period of the cow. Cows in early lactation stage allow higher transmission of AFM1 and this gradually decreases through mid- and late-lactation stages. Lafont, Lafont, Mousset \& Frayssinet (1980) and Veldman, Meijs, Borggreve \& Heeres-van (1992) coincide in that the carry-over of AFM1 in cows in the early lactation period is $3.3-3.5$ times higher than in cows in the late lactation period. Thus, it is important that transmission studies consider the lactation period when milk samples are collected. More studies which analyze dose-dependent transmission are needed.

\section{Multi-exposure and co-occurrence}

Co-occurrence of mycotoxins in feed and food is likely to appear. One type of fungi can produce more than one type of mycotoxins and more than one type of fungi could be present in the same substrate. In addition, mycotoxin metabolites could have similar or more toxic effects than the parent mycotoxin (Mirocha et al., 1981; Valimaa, Kivisto, Leskinen \& Karp, 2010). The co-existence of different mycotoxins within one food product could affect their toxicity, showing additive or even synergistic effects. For instance, the co-occurrence of fumonisins and aflatoxins, even at low concentrations, has synergistic toxicological and carcinogenic effects (Gelderblom, Marasas, LebepeMazur, Swanevelder, Vessey \& Hall Pde, 2002). 
One study suggests that OTA may influence the accumulation of AFM1 in kidney. Shreeve, Patterson \& Roberts (1979) administered OTA and AFB1 daily to 2 Jersey cows and ZEA and AFB1 to another 2 cows for several weeks. Although the AFM1 levels in milk were similar, the kidneys from cows fed with OTA-contaminated diet presented AFM1 levels at least twice as high as those from cows that received ZEA.

Fungi producing CPA are widespread in nature and are able to simultaneously produce aflatoxins (Aspergillus) and ochratoxins (Penicillium). An association between CPA and aflatoxins toxic effects when both are present at the same time was first revealed by a retrospective study on the "Turkey X disease" (Cole, 1986); subsequently, a significant synergism between these two mycotoxins was reported by Pier, Belden, Ellis, Nelson, \& Maki (1989).

Two studies carried out in 2011 and 2012 have analyzed aflatoxins, fumonisins, OTA, ZEA and DON in more than 4000 food samples from all around the world (BIOMIN, 2014). They have shown that only $26 \%$ (2011) and $18 \%$ (2012) of the samples were free of these 5 mycotoxins that were tested. Moreover, the study confirmed the presence of 2 or more types of mycotoxins in at least $41 \%$ of the samples tested in 2011; for the samples tested in 2012 , this percentage increased to $50 \%$.

Most recently, Huang et al. (2014) have detected up to 4 mycotoxins in single milk samples in China. The method they used was able to simultaneously analyze AFM1, OTA, ZEA and $\alpha$-ZEL by UHPLC-MS/MS. Although no sample exceeded the Chinese and EU maximum residue levels for AFM1, of the 50 milk samples tested, $15 \%$ were contaminated with 2 mycotoxins, $45 \%$ for 3 mycotoxins and $22 \%$ for 4 mycotoxins. This finding coincides with a previous Chinese study mentioned by the author (Chen, 2011). 
The MLs in food and feed have been established considering the toxicity of each mycotoxin, but the interaction of different mycotoxins may be not only additive, but also, synergistic (Alassane-Kpembi et al., 2013; Bouaziz, Bouslimi, Kadri, Zaied, Bacha \& Abid-Essefi, 2013; Pier et al., 1989; Tatay, Meca, Font \& Ruiz, 2014). Even at nontoxic concentrations of individual mycotoxins, when together, toxic effects are observed (Wan, Turner \& El-Nezami, 2013). Therefore, since the co-occurrence of them is highly probable in one food, the mere presence of multiple mycotoxins should be considered to be a risky factor even when the values corresponding to each one is below the maximum permitted limit.

\section{Conclusions}

Mycotoxins in milk could be a risk to human and animal health. High contamination in feed may result in a significant mycotoxin level in milk when animals are in a state of physiological imbalance or when they are mainly fed with highly contaminated foodstuff. The increasing efficiency of milk production and the ongoing striving for higher milk yields may facilitate such situations. Several studies performed on different animal species have shown that the transmission of mycotoxins to the milk is possible. Moreover, mycotoxin intake may reduce milk production or alter milk composition. The most studied presence of a mycotoxin in milk has been that of AFM1. It has been studied in samples worldwide, and AFM1 appears as a natural contaminant in the milk of different animals, before or after milk processing. Approximately $10 \%$ of the milk samples analyzed presented AFM1 levels above the maximum level legislated in the EU for this mycotoxin in this human food. The highest occurrence and levels found in the papers which were reviewed are from Asian samples. Few studies have been carried out for monitoring mycotoxins other than AFM1 in milk. Nonetheless, the occurrence of FB1, FB2, OTA, ZEA, ZAN, $\alpha$-ZAL, $\alpha$-ZEL, DOM-1, CPA, AFG1, AFG2, 
AFB1, AFB2 and AFM2 have been detected in natural milk samples, although at low levels. This review shows the importance of continuous monitoring of mycotoxins as natural contaminants in milk regarding the safety aspects of milk and milk products as human food. Moreover, the presence or absence of mycotoxins in milk could be used for indirect analysis of animal health.

Very few studies have been performed for the purpose of analyzing the co-occurrence of more than one type of mycotoxins in milk and, in cases where they co-ocurred, their synergistic or antagonistic effects are unknown. The European Commission recommendations state that "Member States should ensure that samples are simultaneously analyzed for the presence of deoxynivalenol, zearalenone, ochratoxin A, fumonisin $\mathrm{B} 1+\mathrm{B} 2$ and $\mathrm{T}-2$ and $\mathrm{HT}-2$ toxin so that the extent of co-occurrence can be assessed". Analysis of simultaneous mycotoxins in human food and animal feed is an analytical challenge because of the very different physico-chemical characteristics, but it is essential in order to protect human and animal health. Analytical methods that can simultaneously detect and quantify a broad number of mycotoxins, belonging to different families, in milk with low limits of detection and quantification are needed in order to reduce analytical costs and allow more frequent monitoring of mycotoxins in milk. In addition, with these tools, synergistic effects could be studied and better risk assessment could be made.

Furthermore, and due to the fact that dairy animals are mainly contaminated through animal feed, this matrix should be included in studies for monitoring mycotoxin contamination.

\section{Abbreviations Used}

3-acetyldeoxynivalenol (3-ADON), 15-acetyldeoxynivalenol (15-ADON), aflatoxin B1 (AFB1), aflatoxin M1 (AFM1), aflatoxin M2 (AFM2), cyclopiazonic acid (CPA), 
deoxynivalenol (DON), deepoxy-deoxynivalenol (DOM-1), diacetoxyscirpenol (DAS), fumonisin B1 (FB1), fusarenon X (FUS-X), neosolaniol (NEO), nivalenol (NIV), ochratoxin A (OTA), ochratoxin B (OTB), patulin (PAT), sterigmatocystin (STC), toxin T2 (T-2), toxin HT-2 (HT-2), zearalenone (ZEA), zearalanone (ZAN), a-zearalanol ( $\alpha-$ ZAL), $\beta$-zearalanol ( $\beta$-ZAL), $\alpha$-zearalenol ( $\alpha$-ZEL), $\beta$-zearalenol ( $\beta$-ZEL), International Agency for Research on Cancer (IARC), Joint FAO/WHO Expert Committee on Food Additives (JECFA), European Food Safety Authority (EFSA), Provisional Maximum Tolerable Daily Intake (PMTDI), Tolerably Daily Intake (TDI), Limit of Detection (LOD), Limit of Quantification (LOQ).

\section{References}

Aksoy, A., Yavuz, O., Guvenc, D., Das, Y. K., Terzi, G. \& Celik, S. (2010).

Determination of Aflatoxin levels in raw milk, cheese and dehulled hazelnut samples consumed in Samsun Province, Turkey. Kafkas Univ Vet Fak Derg, 16(Suppl-A), S13-S16.

Alassane-Kpembi, I., Kolf-Clauw, M., Gauthier, T., Abrami, R., Abiola, F. A., Oswald, I. P. \& Puel, O. (2013). New insights into mycotoxin mixtures: The toxicity of low doses of Type B trichothecenes on intestinal epithelial cells is synergistic.

Toxicology and Applied Pharmacology, 272(1), 191-198.

doi:10.1016/j.taap.2013.05.023 
Alborzi, S., Pourabbas, B., Rashidi, M. \& Astaneh, B. (2006). Aflatoxin M1 contamination in pasteurized milk in Shiraz (south of Iran). Food Control, 17(7), 582-584. doi:10.1016/j.foodcont.2005.03.009

Alonso, V. A., Monge, M. P., Larriestra, A., Dalcero, A. M., Cavaglieri, L. R. \& Chiacchiera, S. M. (2010). Naturally occurring aflatoxin M1 in raw bulk milk from farm cooling tanks in Argentina. Food Additives \& Contaminants: Part A, 27(3), 373379. doi:10.1080/19440040903403362

Anfossi, L., Baggiani, C., Giovannoli, C. \& Giraudi, G. (2010). Mycotoxins in food and feed: Extraction, analysis and emerging technologies for rapid and on-field detection. Recent Patents on Food, Nutrition \& Agriculture, 2(2), 140-153. doi:10.2174/2212798411002020140

Arast, Y., Mohammadian, M. \& Behnamipour, S. (2012). Occurance of aflatoxin M1 in two dairy products by ELISA in central part of Iran. Life Sci J, 9(3), 1831-1833.

Atanda, O., Oguntubo, A., Adejumo, O., Ikeorah, J. \& Akpan, I. (2007). Aflatoxin M1 contamination of milk and ice cream in Abeokuta and Odeda local governments of Ogun State, Nigeria. Chemosphere, 68(8), 1455-1458.

doi:10.1016/j.chemosphere.2007.03.038

Aydemir Atasever, M., Adiguzel, G., Atasever, M., Ozlu, H. \& Ozturan, K. (2010). Occurrence of Aflatoxin M1 in UHT milk in Erzurum-Turkey. Kafkas Univ Vet Fak Derg, 16(Suppl A), S119-S122.

Battacone, G., Nudda, A., Cannas, A., Cappio Borlino, A., Bomboi, G. \& Pulina, G. (2003). Excretion of aflatoxin M1 in milk of dairy ewes treated with different doses of 
aflatoxin B1. Journal of Dairy Science, 86(8), 2667-2675. doi:10.3168/jds.S00220302(03)73862-4

Bilandžić, N., Varenina, I. \& Solomun, B. (2010). Aflatoxin M1 in raw milk in Croatia. Food Control, 21(9), 1279-1281. doi:10.1016/j.foodcont.2010.03.003

Binder, E. M. (2007). Managing the risk of mycotoxins in modern feed production. Animal Feed Science and Technology, 133(1-2), 149-166. doi:10.1016/j.anifeedsci.2006.08.008

BIOMIN. (2014). Mycotoxin Report., 2014, Retrieved from http://www.biomin.net/fileadmin/user upload/Magazines/MTX Survey/index.html

Blanco, J. L., Domínguez, L., Gómez-Lucía, E., Garayzabal, J. F., García, J. A. \& Suárez, G. (1988). Presence of aflatoxin M1 in commercial ultra-high-temperaturetreated milk. Applied and Environmental Microbiology, 54(6), 1622-1623.

Bognanno, M., La Fauci, L., Ritieni, A., Tafuri, A., De Lorenzo, A., Micari, P., Di Renzo, L., Ciappellano, S., Sarullo, V. \& Galvano, F. (2006). Survey of the occurrence of Aflatoxin M1 in ovine milk by HPLC and its confirmation by MS. Molecular Nutrition \& Food Research, 50(3), 300-305. doi:10.1002/mnfr.200500224

Bouaziz, C., Bouslimi, A., Kadri, R., Zaied, C., Bacha, H. \& Abid-Essefi, S. (2013). The in vitro effects of zearalenone and T-2 toxins on Vero cells. Experimental and Toxicologic Pathology, 65(5), 497-501. doi:10.1016/j.etp.2012.02.005

Boudra, H., Barnouin, J., Dragacci, S. \& Morgavi, D. P. (2007). Aflatoxin M1 and Ochratoxin A in Raw Bulk Milk from French Dairy Herds. Journal of Dairy Science, 90(7), 3197-3201. doi:10.3168/jds.2006-565 
Boudra, H., Le Bars, P. \& Le Bars, J. (1995). Thermostability of Ochratoxin A in wheat under two moisture conditions. Applied and Environmental Microbiology, 61(3), $1156-1158$.

Breitholtz-Emanuelsson, A., Olsen, M., Oskarsson, A., Palminger, I. \& Hult, K. (1993). Ochratoxin A in cow's milk and in human milk with corresponding human blood samples. Journal of AOAC International, 76(4), 842-846.

Breitholtz-Emanuelsson, A., Palminger-Hallén, I., Wohlin, P. O., Oskarsson, A., Hult, K. \& Olsen, M. (1993). Transfer of ochratoxin a from lactating rats to their offspring: A short-term study. Natural Toxins, 1(6), 347-352. doi:10.1002/nt.2620010605

Britzi, M., Friedman, S., Miron, J., Solomon, R., Cuneah, O., Shimshoni, J. A., Soback, S., Ashkenazi, R., Armer, S. \& Shlosberg, A. (2013). Carry-over of aflatoxin B1 to aflatoxin M1 in high yielding Israeli cows in mid- and late-lactation. Toxins, 5(1), 173-183. doi:10.3390/toxins5010173

Bryden, W. L. (2012). Mycotoxin contamination of the feed supply chain: Implications for animal productivity and feed security. Animal Feed Science and Technology, 173(1-2), 134-158. doi:10.1016/j.anifeedsci.2011.12.014

Buckle, A. E. (1983). The occurrence of mycotoxins in cereals and animal feedstuffs. Vet. Res. Commun., 7, 171-186.

Caloni, F., Spotti, M., Auerbach, H., Op den Camp, H., Gremmels, J. F. \& Pompa, G. (2000). In vitro metabolism of fumonisin B1 by ruminal microflora. Veterinary Research Communications, 24(6), 379-387. doi:10.1023/A:1006422200226 
Capriotti, A. L., Caruso, G., Cavaliere, C., Foglia, P., Samperi, R. \& Lagana, A. (2012). Multiclass mycotoxin analysis in food, environmental and biological matrices with chromatography/mass spectrometry. Mass Spectrometry Reviews, 31(4), 466-503. doi:10.1002/mas.20351

Chen, X. Y. (2011). Mycotoxin contamination of feed raw materials and compound feed in some provinces and cities of China in 2009-2010. Zhejiang Journal Animal Science and Veterinary Medicine, 2, 7-9.

Chinese MoH. (2011). National Food Safety Standard. Maximum Levels of Mycotoxins in Foods. GB 2761-2011. Ministry of Health, Peoples Republic of China.

Coffey, R., Cummins, E. \& Ward, S. (2009). Exposure assessment of mycotoxins in dairy milk. Food Control, 20(3), 239-249. doi:10.1016/j.foodcont.2008.05.011

Cole, R. (1986). Etiology of Turkey X disease in retrospect: A case for the involvement of cyclopiazonic acid. Mycotoxin Research, 2(1), 3-7. doi:10.1007/BF03191956

Côté, L. M., Dahlem, A. M., Yoshizawa, T., Swanson, S. P. \& Buck, W. B. (1986). Excretion of deoxynivalenol and its metabolite in milk, urine, and feces of lactating dairy cows. Journal of Dairy Science, 69(9), 2416-2423. doi:10.3168/jds.S00220302(86)80681-6

De Sylos, C. M., Rodriguez-Amaya, D. B. \& Carvalho, P. R. N. (1996). Occurrence of aflatoxin M1 in milk and dairy products commercialized in Campinas, Brazil. Food Additives \& Contaminants, 13(2), 169-172. doi:10.1080/02652039609374395

Decastelli, L., Lai, J., Gramaglia, M., Monaco, A., Nachtmann, C., Oldano, F., Ruffier, M., Sezian, A. \& Bandirola, C. (2007). Aflatoxins occurrence in milk and feed in 
Northern Italy during 2004-2005. Food Control, 18(10), 1263-1266.

doi:10.1016/j.foodcont.2006.08.006

Diaz, G. J. \& Espitia, E. (2006). Occurrence of aflatoxin M1 in retail milk samples from Bogota, Colombia. Food Additives and Contaminants, 23(8), 811-815. doi:10.1080/02652030600681617

Dorner, J. W., Cole, R. J., Erlington, D. J., Suksupath, S., McDowell, G. H. \& Bryden, W. L. (1994). Cyclopiazonic Acid Residues in Milk and Eggs. Journal of Agricultural and Food Chemistry, 42(7), 1516-1518. doi:10.1021/jf00043a023

EFSA. (2005). Opinion of the Scientific Panel on Contaminants in Food Chain on a request from the Commission related to fumonisins as undesirable substances in animal feed. EFSA J, 235, 1-32.

EFSA. (2004a). Opinion of the Scientific Panel on Contaminants in the Food Chain on a request from the Commission related to Zearalenone as undesirable substance in animal feed. EFSA J, 89, 1-35.

EFSA. (2004b). Opinion of the Scientific Panel on Contaminants in the Food Chain on a request from the Commission related to Aflatoxin B1 as undesirable substance in animal feed. EFSA J, 39, 1-27.

El Marnissi, B., Belkhou, R., Morgavi, D. P., Bennani, L. \& Boudra, H. (2012).

Occurrence of aflatoxin M1 in raw milk collected from traditional dairies in Morocco. Food and Chemical Toxicology : An International Journal Published for the British Industrial Biological Research Association, 50(8), 2819-2821.

doi:10.1016/j.fct.2012.05.031 
Elgerbi, A. M., Aidoo, K. E., Candlish, A. A. \& Tester, R. F. (2004). Occurrence of aflatoxin M1 in randomly selected North African milk and cheese samples. Food Additives and Contaminants, 21(6), 592-597. doi:10.1080/02652030410001687690 [doi]

El-Hoshy, S. M. (1999). Occurrence of zearalenone in milk, meat and their products with emphasis on influence of heat treatments on its level. Archiv Für Lebensmittelhygiene, 50, 140-143.

El-Sayed, A. A. A., Neamat-Allah, A. \& Soher, E. A. (2000). Situation of mycotoxins in milk, dairy products and human milk in Egypt. Mycotoxin Research, 16, 91-100. doi:10.1007/BF02946108

El-Tras, W. F., El-Kady, N. N. \& Tayel, A. A. (2011). Infants exposure to aflatoxin M(1) as a novel foodborne zoonosis. Food and Chemical Toxicology : An International Journal Published for the British Industrial Biological Research Association, 49(11), 2816-2819. doi:10.1016/j.fct.2011.08.008

Elzupir, A. O., Makawi, S. Z. A. \& Elhussein, A. M. (2009). Determination of Aflatoxins and Ochratoxin a in Dairy Cattle Feed and Milk in Wad Medani, Sudan. J Anim Vet Adv, 8(12), 2508-2511.

Elzupir, A. O. \& Elhussein, A. M. (2010). Determination of aflatoxin M1 in dairy cattle milk in Khartoum State, Sudan. Food Control, 21(6), 945-946. doi:10.1016/j.foodcont.2009.11.013

European Commission. (2010a). Commission Regulation (EU) N N 165/2010 of 26 February 2010 amending Regulation (EC) No 1881/2006 setting maximum levels for certain contaminants in foodstuffs as regards aflatoxins. $O J L, 50,8-12$. 
European Commission. (2010b). Commission Regulation (EU) No 105/2010 of 5 february 2010 amending Regulation (EC) No 1881-2006 setting maximum levels for certain contaminants in foodstuffs as regards ochratoxin A. OJ L, 35, 7-8.

European Commission. (2007). Commission Regulation (EC) No 1126/2007 of 28 September 2007 amending Regulation (EC) № 1881/2006 setting maximun levels for certain contaminants in foodstuffs as regards Fusarium toxins in maize and maize products. OJ $L, 255,14-17$.

European Commission. (2006). Commission Recommendation of 17 August 2006 on the presence of deoxynivalenol, zearalenone, ochartoxin A, T-2 and HT-2 and fumonisins in products intended for animal feeding (2006/576/EC). OJ L, 229, 7-9.

European Commission. (2003). Commission Directive 2003/100/EC of 31 october 2003 amending Annex I to Directive 2002/32/EC of the European Parliament and of the Council on undesirable substances in animal feed. OJ L, 285, 33-37.

Fallah, A. A. (2010a). Assessment of aflatoxin M1 contamination in pasteurized and UHT milk marketed in central part of Iran. Food and Chemical Toxicology, 48(3), 988-991. doi:10.1016/j.fct.2010.01.014

Fallah, A. A. (2010b). Aflatoxin M1 contamination in dairy products marketed in Iran during winter and summer. Food Control, 21(11), 1478-1481. doi:10.1016/j.foodcont.2010.04.017

FAO. (2004). Worldwide regulations for mycotoxins in food and feed in 2003 Food and Agriculture Organization of The United Nations. The EFSA Journal, 
FAO/WHO. (1995). Codex General Standard for Contaminants and Toxins in Food and Feed. Codex Standars 193-1995. Last modified 2013., 1-48.

FDA. (2005). Compliance Policy Guide, CPG Sec. 527.400 Whole Milk, Lowfat Milk, Skim Milk - Aflatoxin M1, U.S. Food and Drug Administration <br />. Retrieved, May 20, 2014, Retrieved from http://www.fda.gov/ICECI/ComplianceManuals/CompliancePolicyGuidanceManual/ $\underline{\text { ucm074482.htm }}$

Ferrufino-Guardia, E., Tangni, E. K., Larondelle, Y. \& Ponchaut, S. (2000). Transfer of ochratoxin A during lactation: exposure of suckling via the milk of rabbit does fed a naturally-contaminated feed. Food Additives and Contaminants, 17(2), 167-175. doi:10.1080/026520300283522

Fink-Gremmels, J. (2008). Mycotoxins in cattle feeds and carry-over to dairy milk: a review. Food Additives \& Contaminants.Part A, Chemistry, Analysis, Control, Exposure \& Risk Assessment, 25(2), 172-180. doi:10.1080/02652030701823142

Galvano, F., Galofaro, V., Ritieni, A., Bognanno, M., De Angelis, A. \& Galvano, G. (2001). Survey of the occurrence of aflatoxin M1 in dairy products marketed in Italy: second year of observation. Food Additives and Contaminants, 18(7), 644-646. doi:10.1080/02652030118086

Garrido, N. S., Iha, M. H., Santos Ortolani, M. R. \& Duarte Favaro, R. M. (2003). Occurrence of aflatoxins $\mathrm{M}(1)$ and $\mathrm{M}(2)$ in milk commercialized in Ribeirao PretoSP, Brazil. Food Additives and Contaminants, 20(1), 70-73.

doi:10.1080/0265203021000035371 
Gazzotti, T., Lugoboni, B., Zironi, E., Barbarossa, A., Serraino, A. \& Pagliuca, G. (2009). Determination of fumonisin B1 in bovine milk by LC-MS/MS. Food Control, 20(12), 1171-1174. doi:10.1016/j.foodcont.2009.02.009

Gelderblom, W. C., Marasas, W. F., Lebepe-Mazur, S., Swanevelder, S., Vessey, C. J. \& Hall Pde, L. (2002). Interaction of fumonisin B(1) and aflatoxin B(1) in a shortterm carcinogenesis model in rat liver. Toxicology, 171(2-3), 161-173. doi:10.1016/S0300-483X(01)00573-X

Ghanem, I. \& Orfi, M. (2009). Aflatoxin M1 in raw, pasteurized and powdered milk available in the Syrian market. Food Control, 20(6), 603-605. doi:10.1016/j.foodcont.2008.08.018

Goll, M., Valenta, H. \& Oldenburg, E. (1995). Carry-over of zearalenone into bovine milk after longtime application. [Proceedings. 17. Mycotoxin-Workshop at BraunschweigVoelkenrode, FAL], Valenta, H..- Braunschweig (Germany): FAL, Selbstverlag, 1517 May 1995. Landbauforschung Voelkenrode. Sonderheft, 157, 131-134.

González-Osnaya, L., Soriano, J. M., Moltó, J. C. \& Mañes, J. (2008). Simple liquid chromatography assay for analyzing ochratoxin A in bovine milk. Food Chemistry, 108(1), 272-276. doi:10.1016/j.foodchem.2007.10.013

GSO. (2013). General Standard for Contaminants \& Toxins in Food. GCC Standardization Organization (GSO). The Cooperation Council for the Arab States of the Gulf (GCC).

Guan, D., Li, P., Zhang, Q., Zhang, W., Zhang, D. \& Jiang, J. (2011). An ultra-sensitive monoclonal antibody-based competitive enzyme immunoassay for aflatoxin M1 in 
milk and infant milk products. Food Chemistry, 125(4), 1359-1364.

doi:10.1016/j.foodchem.2010.10.006

Gundinc, U. \& Filazi, A. (2009). Detection of aflatoxin M1 concentrations in UHT milk consumed in Turkey markets by ELISA. Pakistan Journal of Biological Sciences: PJBS, 12(8), 653-656.

Guo, Y., Yuan, Y. \& Yue, T. (2013). Aflatoxin m1 in milk products in china and dietary risk assessment. Journal of Food Protection, 76(5), 849-853. doi:10.4315/0362028X.JFP-12-419; 10.4315/0362-028X.JFP-12-419

Gurbay, A., Girgin, G., Sabuncuoglu, S. A., Sahin, G., Yurdakok, M., Yigit, S. \& Tekinalp, G. (2010). Ochratoxin A: is it present in breast milk samples obtained from mothers from Ankara, Turkey? Journal of Applied Toxicology : JAT, 30(4), 329-333. doi:10.1002/jat.1499

Hagler, W. M., Danko, G., Horvath, L., Palyusik, M. \& Mirocha, C. J. (1980).

Transmission of zearalenone and its metabolite into ruminant milk. Acta Veterinaria Academiae Scientiarum Hungaricae, 28(2), 209-216.

Hammer, P., Blüthgen, A. \& Walte, H. G. (1996). Carry-over of fumonisin B1 into the milk of lactating cows. Milk Science International, 51(12), 691-695.

Hassan, H. F. \& Kassaify, Z. (2014). The risks associated with aflatoxins M1 occurrence in Lebanese dairy products. Food Control, 37(0), 68-72.

doi:10.1016/j.foodcont.2013.08.022 
Herzallah, S. M. (2009). Determination of aflatoxins in eggs, milk, meat and meat products using HPLC fluorescent and UV detectors. Food Chemistry, 114(3), 11411146. doi:10.1016/j.foodchem.2008.10.077

Heshmati, A. \& Milani, J. M. (2010). Contamination of UHT milk by aflatoxin M1 in Iran. Food Control, 21(1), 19-22. doi:10.1016/j.foodcont.2009.03.013

Huang, L. C., Zheng, N., Zheng, B. Q., Wen, F., Cheng, J. B., Han, R. W., Xu, X. M., Li, S. L. \& Wang, J. Q. (2014). Simultaneous determination of aflatoxin M1, ochratoxin A, zearalenone and a-zearalenol in milk by UHPLC-MS/MS. Food Chemistry, 146(0), 242-249. doi:10.1016/j.foodchem.2013.09.047

Hussain, I. \& Anwar, J. (2008). A study on contamination of aflatoxin M1 in raw milk in the Punjab province of Pakistan. Food Control, 19(4), 393-395. doi:10.1016/j.foodcont.2007.04.019

Iha, M. H., Barbosa, C. B., Okada, I. A. \& Trucksess, M. W. (2013). Aflatoxin M1 in milk and distribution and stability of aflatoxin M1 during production and storage of yoghurt and cheese. Food Control, 29(1), 1-6. doi:10.1016/j.foodcont.2012.05.058

Indian MoH. (2011). Food Safety and Standard (Contaminants, Toxins and Residues) Regulation. Ministry of Health and Family Welfare. Food Safety and Standards Authority of India., 1-19.

Iqbal, S. Z., Asi, M. R. \& Jinap, S. (2013). Variation of aflatoxin M1 contamination in milk and milk products collected during winter and summer seasons. Food Control, 34(2), 714-718. doi:10.1016/j.foodcont.2013.06.009 
Kamkar, A. (2005). A study on the occurrence of aflatoxin M1 in raw milk produced in Sarab city of Iran. Food Control, 16(7), 593-599.

doi:10.1016/j.foodcont.2004.06.021

Kang'ethe, E. K. \& Lang'a, K. A. (2009). Aflatoxin B1 and M1 contamination of animal feeds and milk from urban centers in Kenya. African Health Sciences, 9(4), 218226.

Keese, C., Meyer, U., Valenta, H., Schollenberger, M., Starke, A., Weber, I. A., Rehage, J., Breves, G. \& Danicke, S. (2008). No carry over of unmetabolised deoxynivalenol in milk of dairy cows fed high concentrate proportions. Molecular Nutrition \& Food Research, 52(12), 1514-1529. doi:10.1002/mnfr.200800077

Kim, E. K., Shon, D. H., Ryu, D., Park, J. W., Hwang, H. J. \& Kim, Y. B. (2000). Occurrence of aflatoxin M1 in Korean dairy products determined by ELISA and HPLC. Food Additives and Contaminants, 17(1), 59-64.

doi:10.1080/026520300283595 [doi]

Kubo, M. (2012). Mycotoxins Legislation Worldwide (last updated February 2012). European Mycotoxins Awareness Network. Leatherhead Food Research. Retrieved, June 13th, 2014, Retrieved from http://services.leatherheadfood.com/eman/FactSheet.aspx?ID=79

Lafont, P., Lafont, J., Mousset, S. \& Frayssinet, C. (1980). Contamination of cow's milk during ingestion of small quantities of aflatoxin. [Etude de la contamination du lait de vache lors de l'ingestion de faibles quantites d'aflatoxine] Annales De La Nutrition Et De L'Alimentation, 34(4), 699-707. 
Le Guevel, R. \& Pakdel, F. (2001). Assessment of oestrogenic potency of chemicals used as growth promoter by in-vitro methods. Human Reproduction (Oxford, England), 16(5), 1030-1036.

López, C. E., Ramos, L. L., Ramadán, S. S. \& Bulacio, L. C. (2003). Presence of aflatoxin M1 in milk for human consumption in Argentina. Food Control, 14(1), 3134. doi:10.1016/S0956-7135(02)00049-X

Losito, I., Monaci, L., Aresta, A. \& Zambonin, C. G. (2002). LC-ion trap electrospray MSMS for the determination of cyclopiazonic acid in milk samples. The Analyst, 127(4), 499-502.

Mally, A., Keim-Heusler, H., Amberg, A., Kurz, M., Zepnik, H., Mantle, P., Volkel, W., Hard, G. C. \& Dekant, W. (2005). Biotransformation and nephrotoxicity of ochratoxin B in rats. Toxicology and Applied Pharmacology, 206(1), 43-53. doi:10.1016/j.taap.2004.11.007

Maqbool, U., Anwar-Ul-Haq \& Ahmad, M. (2009). ELISA determination of Aflatoxin M1 in milk and dairy products in Pakistan. Toxicological \& Environmental Chemistry, 91(2), 241-249. doi:10.1080/02772240802144562

Maragos, C. M. \& Richard, J. L. (1994). Quantitation and stability of fumonisins B1 and B2 in milk. Journal of AOAC International, 77(5), 1162-1167.

Markaki, P. \& Melissari, E. (1997). Occurrence of aflatoxin M1 in commercial pasteurized milk determined with ELISA and HPLC. Food Additives and Contaminants, 14(5), 451-456. doi:10.1080/02652039709374551 
Martins, M. L. \& Martins, H. M. (2000). Aflatoxin M1 in raw and ultra high temperaturetreated milk commercialized in Portugal. Food Additives \& Contaminants, 17(10), 871-874. doi:10.1080/026520300420457

Masoero, F., Gallo, A., Moschini, M., Piva, G. \& Diaz, D. (2007). Carryover of aflatoxin from feed to milk in dairy cows with low or high somatic cell counts. Animal : An International Journal of Animal Bioscience, 1(9), 1344-1350. doi:10.1017/S1751731107000663; 10.1017/S1751731107000663

MERCOSUR. (2002). Reglamento técnico MERCOSUR sobre límites máximos de aflatoxinas admisibles en leche,maní y maíz. GMC/RES, No 25/02, 1-7.

Mirocha, C. J., Pathre, S. V. \& Robison, T. S. (1981). Comparative metabolism of zearalenone and transmission into bovine milk. Food and Cosmetics Toxicology, 19(1), 25-30.

Mohamadi Sani, A., Nikpooyan, H. \& Moshiri, R. (2010). Aflatoxin M1 contamination and antibiotic residue in milk in Khorasan province, Iran. Food and Chemical Toxicology, 48(8-9), 2130-2132. doi:10.1016/j.fct.2010.05.015

Mohamadi, H. \& Alizadeh, M. (2010). A Study of the Occurence of Aflatoxin M1 in Dairy Products Marketed in Urmia, Iran. J. Agr. Sci. Tech., 12, 579-583.

Nachtmann, C., Gallina, S., Rastelli, M., Ferro, G. L. \& Decastelli, L. (2007). Regional monitoring plan regarding the presence of aflatoxin $\mathrm{M} 1$ in pasteurized and UHT milk in Italy. Food Control, 18(6), 623-629. doi:10.1016/j.foodcont.2006.01.001

Nakajima, M., Tabata, S., Akiyama, H., Itoh, Y., Tanaka, T., Sunagawa, H., Tyonan, T., Yoshizawa, T. \& Kumagai, S. (2004). Occurrence of aflatoxin M1 in domestic milk in 
Japan during the winter season. Food Additives \& Contaminants, 21(5), 472-478. doi:10.1080/02652030410001677817

Navas, S. A., Sabino, M. \& Rodriguez-Amaya, D. B. (2005). Aflatoxin M(1) and ochratoxin A in a human milk bank in the city of Sao Paulo, Brazil. Food Additives and Contaminants, 22(5), 457-462. doi:10.1080/02652030500110550

Nemati, M., Mehran, M. A., Hamed, P. K. \& Masoud, A. (2010). A survey on the occurrence of aflatoxin M1 in milk samples in Ardabil, Iran. Food Control, 21(7), 1022-1024. doi:10.1016/j.foodcont.2009.12.021

Offiah, N. \& Adesiyun, A. (2007). Occurrence of aflatoxins in peanuts, milk, and animal feed in Trinidad. Journal of Food Protection, 70(3), 771-775.

Oliveira, C. A. \& Ferraz, J. C. O. (2007). Occurrence of aflatoxin M1 in pasteurised, UHT milk and milk powder from goat origin. Food Control, 18(4), 375-378. doi:10.1016/j.foodcont.2005.11.003

Oliveira, C. A., Rosmaninho, J. \& Rosim, R. (2006a). Aflatoxin M1 and cyclopiazonic acid in fluid milk traded in SÃ£o Paulo, Brazil. Food Additives and Contaminants, 23(2), 196-201. doi:10.1080/02652030500398379

Oliveira, C. A., Rosmaninho, J. \& Rosim, R. (2006b). Aflatoxin M1 and cyclopiazonic acid in fluid milk traded in São Paulo, Brazil. Food Additives and Contaminants, 23(2), 196-201. doi:10.1080/02652030500398379

Oliveira, C. A., Germano, P. M., Bird, C. \& Pinto, C. A. (1997). Immunochemical assessment of aflatoxin M1 in milk powder consumed by infants in Sao Paulo, 
Brazil. Food Additives and Contaminants, 14(1), 7-10.

doi:10.1080/02652039709374491 [doi]

Omar, S. S. (2012). Incidence of Aflatoxin M1 in Human and Animal Milk in Jordan. Journal of Toxicology and Environmental Health, Part A, 75(22-23), 1404-1409. doi:10.1080/15287394.2012.721174

Oveisi, M., Jannat, B., Sadeghi, N., Hajimahmoodi, M. \& Nikzad, A. (2007). Presence of aflatoxin M1 in milk and infant milk products in Tehran, Iran. Food Control, 18(10), 1216-1218. doi:10.1016/j.foodcont.2006.07.021

Ozsunar, A., Gumus, T., Arici, M. \& Demirci, M. (2010). Occurrence of Aflatoxin M1 in raw milk in Trakya Region, Turkey. Asian J. Chem., 22(3), 1879-1884.

Panariti, E. (2001). Seasonal variations of aflatoxin M1 in the farm milk in Albania. Arh Hig Rada Toksikol, 52, 37-41.

Pattono, D., Gallo, P. F. \& Civera, T. (2011). Detection and quantification of Ochratoxin A in milk produced in organic farms. Food Chemistry, 127(1), 374-377. doi:10.1016/j.foodchem.2010.12.051

Pier, A. C., Belden, E. L., Ellis, J. A., Nelson, E. W. \& Maki, L. R. (1989). Effects of cyclopiazonic acid and aflatoxin singly and in combination on selected clinical, pathological and immunological responses of guinea pigs. Mycopathologia, 105(3), 135-142. doi:10.1007/BF00437245

Pietri, A., Bertuzzi, T., Moschini, M. \& Piva, G. (2003). Aflatoxin M1 occurrence in milk samples destined for parmigiano reggio cheese production. Ital. J. Food Sci, 15(2), 301-306. 
Pietri, A., Bertuzzi, T., Piva, G., Binder, E. M., Schatzmayr, D. \& Rodrigues, I. (2009). Aflatoxin Transfer from Naturally Contaminated Feed to Milk of Dairy Cows and the Efficacy of a Mycotoxin Deactivating Product.<br >. Int. J. Dairy Sci., 4(2), 34-42.

Poapolathep, A., Sugita Konishi, Y., Phitsanu, T., Doi, K. \& Kumagai, S. (2004). Placental and milk transmission of trichothecene mycotoxins, nivalenol and fusarenon-X, in mice. Toxicon, 44(1), 111-113. doi:10.1016/j.toxicon.2004.04.005

Prandini, A., Tansini, G., Sigolo, S., Filippi, L., Laporta, M. \& Piva, G. (2009). On the occurrence of aflatoxin M1 in milk and dairy products. Food and Chemical Toxicology : An International Journal Published for the British Industrial Biological Research Association, 47(5), 984-991. doi:10.1016/j.fct.2007.10.005

Prelusky, D. B., Trenholm, H. L., Rotter, B. A., Miller, J. D., Savard, M. E., Yeung, J. M. \& Scott, P. M. (1996). Biological fate of fumonisin B1 in food-producing animals. Advances in Experimental Medicine and Biology, 392, 265-278.

Prelusky, D. B., Scott, P. M., Trenholm, H. L. \& Lawrence, G. A. (1990). Minimal transmission of zearalenone to milk of dairy cows. Journal of Environmental Science and Health.Part.B, Pesticides, Food Contaminants, and Agricultural Wastes, 25(1), 87-103. doi:10.1080/03601239009372678

Prelusky, D. B., Veira, D. M., Trenholm, H. L. \& Foster, B. C. (1987). Metabolic fate and elimination in milk, urine and bile of deoxynivalenol following administration to lactating sheep. Journal of Environmental Science and Health.Part.B, Pesticides, Food Contaminants, and Agricultural Wastes, 22(2), 125-148.

doi:10.1080/10934528709375339 
Prelusky, D. B., Trenholm, H. L., Lawrence, G. A. \& Scott, P. M. (1984).

Nontransmission of deoxynivalenol (vomitoxin) to milk following oral administration to dairy cows. Journal of Environmental Science and Health, Part B, 19(7), 593609. doi: $10.1080 / 03601238409372453$

Puel, O., Galtier, P. \& Oswald, I. P. (2010). Biosynthesis and toxicological effects of patulin. Toxins, 2(4), 613-631. doi:10.3390/toxins2040613 [doi]

Rahimi, E., Bonyadian, M., Rafei, M. \& Kazemeini, H. R. (2010). Occurrence of aflatoxin M1 in raw milk of five dairy species in Ahvaz, Iran. Food and Chemical Toxicology, 48(1), 129-131. doi:10.1016/j.fct.2009.09.028

Rastogi, S., Dwivedi, P. D., Khanna, S. K. \& Das, M. (2004). Detection of Aflatoxin M1 contamination in milk and infant milk products from Indian markets by ELISA. Food Control, 15(4), 287-290. doi:10.1016/S0956-7135(03)00078-1

Reyes Velázquez, W., Patricio Martínez, S., Isaías Espinosa, V. H., Nathal Vera, M. A., De Lucas Palacios, E. \& Rojo, F. (2009). Total aflatoxins in cows feed and AFM1 in milk in dairy herds from Jalisco State, Mexico. Téc Pecu Méx, 47(2), 223-230.

Riahi-Zanjani, B. \& Balali-Mood, M. (2013). Aflatoxin M1 contamination in commercial pasteurized milk from local markets in Fariman, Iran. Mycotoxin Research, 29(4), 271-274. doi:10.1007/s12550-013-0179-6; 10.1007/s12550-013-0179-6

Ribelin, W. E., Fukushima, K. \& Still, P. E. (1978). The toxicity of ochratoxin to ruminants. Canadian Journal of Comparative Medicine, 42(2), 172-176.

Richard, J. L., Meerdink, G., Maragos, C. M., Tumbleson, M., Bordson, G., Rice, L. G. \& Ross, P. F. (1996). Absence of detectable fumonisins in the milk of cows fed 
Fusarium proliferatum (Matsushima) Nirenberg culture material. Mycopathologia, 133(2), 123-126.

Rodriguez Velasco, M. L., Calonge Delso, M. M. \& Ordonez Escudero, D. (2003). ELISA and HPLC determination of the occurrence of aflatoxin M(1) in raw cow's milk. Food Additives and Contaminants, 20(3), 276-280.

doi:10.1080/0265203021000045208

Roussi, V., Govaris, A., Varagouli, A. \& Botsoglou, N. A. (2002). Occurrence of aflatoxin $\mathrm{M}(1)$ in raw and market milk commercialized in Greece. Food Additives and Contaminants, 19(9), 863-868. doi:10.1080/02652030210146864

Ruangwises, N. \& Ruangwises, S. (2010). Aflatoxin M(1) contamination in raw milk within the central region of Thailand. Bulletin of Environmental Contamination and Toxicology, 85(2), 195-198. doi:10.1007/s00128-010-0056-3

Sándor, G. (1984). Occurrence of mycotoxins in feeds, animal organs and secretions. Acta Veterinaria Hungarica, 32(1-2), 57-69.

Sani, A. M. \& Nikpooyan, H. (2012). Determination of aflatoxin M1 in milk by highperformance liquid chromatography in Mashhad (north east of Iran). Toxicology and Industrial Health,

Santini, A., Raiola, A., Ferrantelli, V., Giangrosso, G., Macaluso, A., Bognanno, M., Galvano, F. \& Ritieni, A. (2013). Aflatoxin M1 in raw, UHT milk and dairy products in Sicily (Italy). Food Additives \& Contaminants: Part B, 6(3), 181-186.

doi:10.1080/19393210.2013.780186 
SCOOP. (2003). Task 3.2.10 Collection of occurrence data of Fusarium toxins in food and assessment of dietary intake by the population of EU member states. Subtask II: zearalenone. European Commission, Directorate-General Health and Consumer Protection. Scientific Cooperation on Questions Relating to Food., 239-482.

Scott, P. M., Delgado, T., Prelusky, D. B., Trenholm, H. L. \& Miller, J. D. (1994). Determination of fumonisins in milk. Journal of Environmental Science and Health.Part.B, Pesticides, Food Contaminants, and Agricultural Wastes, 29(5), 989998. doi:10.1080/03601239409372913

Secretaría Mexicana de Salud. (2002). Norma Oficial Mexicana NOM-184-SSA1-2002, Productos y servicios. Leche, fórmula láctea y producto lácteo combinado. Especificaciones sanitarias. Estados Unidos Mexicanos, Secretaría de Salud. Diario Oficial, (Segunda sección), 1-55.

Seeling, K., Danicke, S., Valenta, H., Van Egmond, H. P., Schothorst, R. C., Jekel, A. A., Lebzien, P., Schollenberger, M., Razzazi-Fazeli, E. \& Flachowsky, G. (2006). Effects of Fusarium toxin-contaminated wheat and feed intake level on the biotransformation and carry-over of deoxynivalenol in dairy cows. Food Additives and Contaminants, 23(10), 1008-1020. doi:10.1080/02652030600723245

Sefidgar, S. A., Mirzae, M., Assmar, M. \& Naddaf, S. R. (2011). Aflatoxin M1 in Pasteurized Milk in babol city, Mazandaran Province, Iran. Iranian J Publ Health, 40(1), 115-118.

Sefidgar, S. A., Azizi, G., Khosravi, A. R. \& Roudbar-Mohammadi, S. (2008). Presence of Aflatoxin M1 in raw milk at cattle farms in Babol, Iran. Pakistan Journal of Biological Sciences: PJBS, 11(3), 484-486. 
Shreeve, B. J., Patterson, D. S. \& Roberts, B. A. (1979). The 'carry-over' of aflatoxin, ochratoxin and zearalenone from naturally contaminated feed to tissues, urine and milk of dairy cows. Food and Cosmetics Toxicology, 17(2), 151-152.

Skaug, M. A. (1999). Analysis of Norwegian milk and infant formulas for ochratoxin A. Food Additives and Contaminants, 16(2), 75-78. doi:10.1080/026520399284235

Sørensen, L. K. \& Elbæk, T. H. (2005). Determination of mycotoxins in bovine milk by liquid chromatography tandem mass spectrometry. Journal of Chromatography.B, Analytical Technologies in the Biomedical and Life Sciences, 820(2), 183-196. doi:10.1016/j.jchromb.2005.03.020

South African MoH. (2004). Foodstuffs, Cosmetics and Disinfectant Act 1972 (ACT No 54 of 1972) Regulations Governing Tolerance for Fungus-produced Toxins in Foodstuffs . Government Gazette, No. 26849(R1145), 6-7.

Spotti, M., Caloni, F., Fracchiolla, L., Pompa, G., Vigo, D. \& Maffeo, G. (2001). Fumonisin B1 carry-over into milk in the isolated perfused bovine udder. Veterinary and Human Toxicology, 43(2), 109-111.

Srivastava, V. P., Bu-Abbas, A., Alaa-Basuny, Al-Johar, W., Al-Mufti, S. \& Siddiqui, M. K. (2001). Aflatoxin M1 contamination in commercial samples of milk and dairy products in Kuwait. Food Additives and Contaminants, 18(11), 993-997. doi:10.1080/02652030110050357

Stoloff, L. (1997). Aflatoxins: an overview. In: Proceedings of a Conference on Mycotoxins in Human and Animal Health. Pathotox Publisher Inc. Park Forest South, illinois., 7-28. 
Sugiyama, K., Hiraoka, H. \& Sugita-Konishi, Y. (2008). Aflatoxin M1 contamination in raw bulk milk and the presence of aflatoxin B1 in corn supplied to dairy cattle in Japan. Shokuhin Eiseigaku Zasshi.Journal of the Food Hygienic Society of Japan, 49(5), 352-355.

Tajik, H., Rohani, S. M. \& Moradi, M. (2007). Detection of aflatoxin M1 in raw and commercial pasteurized milk in Urmia, Iran. Pakistan Journal of Biological Sciences: PJBS, 10(22), 4103-4107.

Tajkarimi, M., Aliabadi-Sh, F., Salah Nejad, A., Poursoltani, H., Motallebi, A. A. \& Mahdavi, H. (2008). Aflatoxin M1 contamination in winter and summer milk in 14 states in Iran. Food Control, 19(11), 1033-1036. doi:10.1016/j.foodcont.2007.10.011

Tajkarimi, M., Shojaee Aliabadi, F., Salah Nejad, M., Pursoltani, H., Motallebi, A. A. \& Mahdavi, H. (2007). Seasonal study of aflatoxin M1 contamination in milk in five regions in Iran. International Journal of Food Microbiology, 116(3), 346-349. doi:10.1016/j.jijfoodmicro.2007.02.008

Taniwaki, M. H., Silva, N., Banhe, A. A. \& Lamanaka, B. T. (2001). Comparison of culture media, simplate, and petrifilm for enumeration of yeasts and molds in food. Journal of Food Protection, 64(10), 1592-1596.

Tatay, E., Meca, G., Font, G. \& Ruiz, M. (2014). Interactive effects of zearalenone and its metabolites on cytotoxicity and metabolization in ovarian $\mathrm{CHO}-\mathrm{K} 1$ cells. Toxicology in Vitro, 28(1), 95-103. doi:10.1016/j.tiv.2013.06.025

Thirumala-Devi, K., Mayo, M. A., Hall, A. J., Craufurd, P. Q., Wheeler, T. R., Waliyar, F., Subrahmanyam, A. \& Reddy, D. V. (2002). Development and application of an 
indirect competitive enzyme-linked immunoassay for aflatoxin $\mathrm{m}(1)$ in milk and milkbased confectionery. Journal of Agricultural and Food Chemistry, 50(4), 933-937.

Tian, H. \& Liu, X. (2004). Survey and analysis on sterigmatocystin contaminated in grains in China. Wei Sheng Yan Jiu = Journal of Hygiene Research, 33(5), 606608.

Tsakiris, I. N., Tzatzarakis, M. N., Alegakis, A. K., Vlachou, M. I., Renieri, E. A. \& Tsatsakis, A. M. (2013). Risk assessment scenarios of children's exposure to aflatoxin M1 residues in different milk types from the Greek market. Food and Chemical Toxicology, 56(0), 261-265. doi:10.1016/j.fct.2013.02.024

Unusan, N. (2006). Occurrence of aflatoxin M1 in UHT milk in Turkey. Food and Chemical Toxicology, 44(11), 1897-1900. doi:10.1016/j.fct.2006.06.010

Usleber, E., Renz, V., Martlbauer, E. \& Terplan, G. (1992). Studies on the application of enzyme immunoassays for the Fusarium mycotoxins deoxynivalenol, 3acetyldeoxynivalenol, and zearalenone. Zentralblatt Fur Veterinarmedizin.Reihe B.Journal of Veterinary Medicine.Series B, 39(8), 617-627.

Valimaa, A. L., Kivisto, A. T., Leskinen, P. I. \& Karp, M. T. (2010). A novel biosensor for the detection of zearalenone family mycotoxins in milk. Journal of Microbiological Methods, 80(1), 44-48. doi:10.1016/j.mimet.2009.10.017

Veldman, A., Meijs, J. A. C., Borggreve, G. J. \& Heeres-van, d. T. (1992). Carry-over of aflatoxin from cows' food to milk. Animal Science, 55(02), 163-168. 
Versilovskis, A. \& De Saeger, S. (2010). Sterigmatocystin: occurrence in foodstuffs and analytical methods--an overview. Molecular Nutrition \& Food Research, 54(1), $136-$ 147. doi:10.1002/mnfr.200900345

Versilovskis, A., Van Peteghem, C. \& De Saeger, S. (2009). Determination of sterigmatocystin in cheese by high-performance liquid chromatography-tandem mass spectrometry. Food Additives \& Contaminants.Part A, Chemistry, Analysis, Control, Exposure \& Risk Assessment, 26(1), 127-133.

doi:10.1080/02652030802342497; 10.1080/02652030802342497

Wan, L. Y. M., Turner, P. C. \& El-Nezami, H. (2013). Individual and combined cytotoxic effects of Fusarium toxins (deoxynivalenol, nivalenol, zearalenone and fumonisins B1) on swine jejunal epithelial cells. Food and Chemical Toxicology, 57(0), 276283. doi:10.1016/j.fct.2013.03.034

Wang, H., Zhou, X. J., Liu, Y. Q., Yang, H. M. \& Guo, Q. L. (2011). Simultaneous determination of chloramphenicol and aflatoxin $\mathrm{M} 1$ residues in milk by triple quadrupole liquid chromatography-tandem mass spectrometry. Journal of Agricultural and Food Chemistry, 59(8), 3532-3538. doi:10.1021/jf2006062

Wang, H., Zhou, X. J., Liu, Y. Q., Yang, H. M. \& Guo, Q. L. (2010). Determination of aflatoxin M1 in milk by triple quadrupole liquid chromatography-tandem mass spectrometry. Food Additives \& Contaminants.Part A, Chemistry, Analysis, Control, Exposure \& Risk Assessment, 27(9), 1261-1265.

doi:10.1080/19440049.2010.487501

Wang, Y., Liu, X., Xiao, C., Wang, Z., Wang, J., Xiao, H., Cui, L., Xiang, Q. \& Yue, T. (2012). HPLC determination of aflatoxin M1 in liquid milk and milk powder using 
solid phase extraction on OASIS HLB. Food Control, 28(1), 131-134.

doi:10.1016/j.foodcont.2012.04.037

Whitlow, L. W., Diaz, D. E., Hopkins, B. A. \& Hagler, W. M. (2006). Mycotoxins and milk safety: the potential to block transfer to milk., 2013, Retrieved from http://en.engormix.com/MA-mycotoxins/articles/mycotoxins-milk-safety-potential$\underline{\mathrm{t} 199 / \mathrm{p} 0 . \mathrm{htm}}$

Winkler, J., Kersten, S., Meyer, U., Engelhardt, U. \& Dänicke, S. (2014). Residues of zearalenone (ZEN), deoxynivalenol (DON) and their metabolites in plasma of dairy cows fed Fusarium contaminated maize and their relationships to performance parameters. Food and Chemical Toxicology, 65(0), 196-204.

doi:10.1016/j.fct.2013.12.020

Xia, X., Li, X., Ding, S., Zhang, S., Jiang, H., Li, J. \& Shen, J. (2009). Ultra-highpressure liquid chromatography-tandem mass spectrometry for the analysis of six resorcylic acid lactones in bovine milk. Journal of Chromatography.A, 1216(12), 2587-2591. doi:10.1016/j.chroma.2009.01.033

Yoshizawa, T., Mirocha, C. J., Behrens, J. C. \& Swanson, S. P. (1981). Metabolic fate of T-2 toxin in a lactating cow. Food and Cosmetics Toxicology, 19(1), 31-39. doi:10.1016/0015-6264(81)90300-X

Zhang, D. H., Li, P. W., Zhang, Q., Yang, Y., Zhang, W., Guan, D., \& Ding, X. X. (2012). Extract-free immunochromatographic assay for on-site tests of aflatoxin M1 in milk The Royal Society of Chemistry. doi:- 10.1039/C2AY25205H 
Zinedine, A., González-Osnaya, L., Soriano, J. M., Moltó, J. C., Idrissi, L. \& Mañes, J. (2007). Presence of aflatoxin M1 in pasteurized milk from Morocco. International Journal of Food Microbiology, 114(1), 25-29. doi:10.1016/j.ijfoodmicro.2006.11.001

\section{Financial support}

We wish to thank the Programa de Investigación Universidad de Navarra (PIUNA) for the financial support. MFF wish to thanks "Asociación de Amigos de la Universidad de Navarra" (ADA) for the grant funding. 


\begin{tabular}{|c|c|c|}
\hline Country & Foodstuffs & Aflatoxin Mu maximun level \\
\hline $\begin{array}{c}\text { Austria, Belgium, Bosnia and Herzegovina, Cyprus, Denmark, Finland, France, } \\
\text { Germany, Greece, Iceland, Ireland, Italy, Liechtenstein, Lithuania, Luxembourg, } \\
\text { Netherlands, Norway, Poland, Portugal, Slovenia, Spain, Sweden, Turkey, United } \\
\text { Kingdom, EU (European Commission, 2010a) }\end{array}$ & \multirow[t]{2}{*}{$\begin{array}{l}\text { Raw milk, heat-treated milk and milk for the manufacturer of } \\
\text { milk-based products }\end{array}$} & \multirow[t]{2}{*}{$0.050 \mu \mathrm{g} / \mathrm{kg}$} \\
\hline $\begin{array}{l}\text { Saudi Arabia, United Arab Emirates, Kuwait, Bahrain, Oman, Qatar, GCC (GSO, } \\
\text { 2013) }\end{array}$ & & \\
\hline $\begin{array}{l}\text { Belarus, Bulgaria, Chile, Czech Republic, Estonia, Honduras, Hungary, Iran (Islamic } \\
\text { Republic of), Israel, Malta, Morocco, Switzerland, Turkey(FAO, 2004) }\end{array}$ & Milk & $0.05 \mu \mathrm{g} / \mathrm{kg}$ \\
\hline \multirow{2}{*}{$\begin{array}{l}\text { Argentina, Brazil, Paraguay, Uruguay, } \\
\text { MERCOSUR(2002) }\end{array}$} & Fluid milk & $0.5 \mu \mathrm{g} / \mathrm{L}$ \\
\hline & Powder milk & $5 \mu \mathrm{g} / \mathrm{kg}$ \\
\hline Codex Alimentarius (FAO/WHO, 1995) & \multirow{6}{*}{ Milk } & \multirow{6}{*}{$0.5 \mu \mathrm{g} / \mathrm{kg}$} \\
\hline USA (FDA, 2005) & & \\
\hline India (Indian MoH, 2011) & & \\
\hline South Africa (South African MoH, 2004) & & \\
\hline Kenya (Kubo, 2012) & & \\
\hline $\begin{array}{c}\text { Armenia, Barbados, Croatia, South Korea, Latvia, Republic of Moldova, Montenegro, } \\
\text { Peru, Romania, Russian Federation, Serbia, Singapore, Slovakia, Taiwan, Ukraine, } \\
\text { Venezuela, Vietnam (FAO, 2004) }\end{array}$ & & \\
\hline China (Chinese MoH, 2011) & $\begin{array}{l}\text { Milk and milk products (for milk powder, calculated on a fresh } \\
\text { milk basis) }\end{array}$ & $0.5 \mu \mathrm{g} / \mathrm{kg}$ \\
\hline Mexico (Secretaría Mexicana de Salud, 2002) & $\begin{array}{l}\text { Pasteurised, ultrapasteurised, sterilised and dehydrated milk, } \\
\text { milk formula and combined milk products }\end{array}$ & $0.5 \mu \mathrm{g} / \mathrm{L}$ \\
\hline \multirow[t]{2}{*}{ Syria (FAO, 2004) } & Liquid milk & $0.2 \mu \mathrm{g} / \mathrm{kg}$ \\
\hline & Dried milk (not used in baby food) & $0.05 \mu \mathrm{g} / \mathrm{kg}$ \\
\hline Indonesia (FAO, 2004) & Milk & $5 \mu \mathrm{g} / \mathrm{kg}$ \\
\hline
\end{tabular}

EU: European Union, GCC: Cooperation Council for the Arab States of the Gulf. MoH:Ministry of Health. 
Table 2. Occurrence of mycotoxins in animal milk samples worldwide.

\begin{tabular}{|c|c|c|c|c|c|c|c|c|c|}
\hline Mycotoxin & Milk origin & $\begin{array}{c}\text { Collection } \\
\text { year }\end{array}$ & Milk type & $\begin{array}{c}\text { Total } \\
\text { samples }\end{array}$ & $\begin{array}{l}\text { Number of } \\
\text { positive } \\
\text { samples }\end{array}$ & $\begin{array}{c}\% \\
\text { positive } \\
\text { sample }\end{array}$ & $\begin{array}{c}\text { Mycotoxin } \\
\text { concentration }\end{array}$ & Method of analysis & Reference \\
\hline \multirow{2}{*}{ FB1 } & USA & 1993 & $\mathrm{R}$ & 155 & 1 & 0.6 & $1290 \mathrm{ng} / \mathrm{L}$ & GC/MS & (Maragos \& Richard, 1994) \\
\hline & Italy & n.r. & $\mathrm{R}, \mathrm{P}, \mathrm{O}$ & 10 & 8 & 80 & $260^{\mathrm{a}} 430^{\mathrm{b}} \mathrm{ng} / \mathrm{kg}$ & LC-MS/MS-QQQ & (Gazzotti et al., 2009) \\
\hline \multirow{2}{*}{ CPA } & Italy & n.r. & $P$ & 20 & 3 & 15 & $6333^{\mathrm{a}} 8300^{\mathrm{b}} \mathrm{ng} / \mathrm{L}$ & LC-MS/MS-ion trap & (Losito et al., 2002) \\
\hline & Brazil & 2004 & $P, U$ & 48 & 2 & 4.2 & 8 050a $9700^{b} \mathrm{ng} / \mathrm{L}$ & LC-UV-VIS & (Oliveira, Rosmaninho \& Rosim, 2006b) \\
\hline \multirow{9}{*}{ ZEA } & Hungary & 1980 & $\mathrm{R}$ & n.r & 16 & n.r & n.r. & TLC-UV and GC & (Sándor, 1984) \\
\hline & \multirow{4}{*}{ Egypt } & \multirow{4}{*}{ n.r. } & $\mathrm{R}$ & 20 & 4 & 20 & $6900^{\mathrm{a}} 10100^{\mathrm{b}} \mathrm{ng} / \mathrm{kg}$ & \multirow{4}{*}{ LC-FLD } & \multirow{4}{*}{ (El-Hoshy, 1999) } \\
\hline & & & $\mathrm{P}$ & 20 & 3 & 15 & $5000^{a} \quad 7200^{b} \mathrm{ng} / \mathrm{kg}$ & & \\
\hline & & & $D$ & 20 & 6 & 30 & $6400^{\mathrm{a}} \quad 12500^{\mathrm{b}} \mathrm{ng} / \mathrm{kg}$ & & \\
\hline & & & C & 20 & 5 & 25 & $4400^{\mathrm{a}} 9300^{\mathrm{b}} \mathrm{ng} / \mathrm{kg}$ & & \\
\hline & UK & n.r. & n.r. & 100 & 3 & 3 & $500^{a} 5500^{b} \mathrm{ng} / \mathrm{kg}$ & n.r. & (SCOOP, 2003) \\
\hline & \multirow{3}{*}{ China } & \multirow{3}{*}{2012} & $\mathrm{R}$ & 30 & n.r & n.r & $14.9^{a} 45.8^{b} \mathrm{ng} / \mathrm{kg}$ & \multirow{3}{*}{ UHPLC-MS/MS } & \multirow{3}{*}{ (Huang et al., 2014) } \\
\hline & & & $D$ & 8 & n.r & n.r & $11.6^{a} 12.4^{b} \mathrm{ng} / \mathrm{kg}$ & & \\
\hline & & & L & 12 & n.r & n.r & $20.5^{\text {a }} 28.3^{b} \mathrm{ng} / \mathrm{kg}$ & & \\
\hline ZAN & \multirow{2}{*}{ China } & \multirow{2}{*}{ n.r. } & n.r & 103 & 1 & 0.97 & 370 ng/L & \multirow{2}{*}{ LC-MS/MS-QQQ } & \multirow[t]{2}{*}{ (Xia et al., 2009) } \\
\hline$a-Z A L$ & & & n.r & 103 & 1 & 0.97 & 3030 ng/L & & \\
\hline \multirow{3}{*}{ a-ZEL } & \multirow{3}{*}{ China } & \multirow{3}{*}{2012} & $\mathrm{R}$ & 30 & n.r & n.r & $24.3^{a} 73.5^{b} \mathrm{ng} / \mathrm{kg}$ & \multirow{3}{*}{ UHPLC-MS/MS } & \multirow{3}{*}{ (Huang et al., 2014) } \\
\hline & & & $D$ & 8 & $n . r$ & n.r & $43.1^{\text {a }} 64.3^{b} \mathrm{ng} / \mathrm{kg}$ & & \\
\hline & & & $L$ & 12 & n.r & n.r & $36.7^{\text {a }} 45.1^{b} \mathrm{ng} / \mathrm{kg}$ & & \\
\hline DOM-1 & Denmark & n.r. & $\mathrm{R}$ & 20 & 5 & 25 & $180^{\mathrm{a}} \mathrm{ng} / \mathrm{L} 300^{\mathrm{b}} \mathrm{ng} / \mathrm{L}$ & LC-MS/MS & (Sørensen \& Elbæk, 2005) \\
\hline
\end{tabular}

${ }^{a}$ mean value, ${ }^{b}$ maximum value,$C=$ condensed cow milk, $\mathrm{D}=$ powder cow milk, $\mathrm{P}=$ pasteurized cow milk, $\mathrm{R}=$ raw cow milk, $\mathrm{L}=$ liquid cow milk, $\mathrm{O}=$ organic, $\mathrm{U}=\mathrm{UHT}$ treated, n.r. $=$ not reported. $\mathrm{GC}=$ gas chromatography, $\mathrm{LC}=$ liquid chromatography, UHPLC $=$ ultra high pressure liquid chromatography, $\mathrm{TLC}=$ thin layer

chromatography, $\mathrm{FLD}=$ fluorescence detector, UV-VIS = ultraviolet and visible detector, $M S / M S=$ tandem mass spectrometry, $Q Q Q=$ triple quadrupole, IPC = ion-pair 


\begin{tabular}{|c|c|c|c|c|c|c|c|c|c|}
\hline Mycotoxin & Milk origin & $\begin{array}{c}\text { Collection } \\
\text { year }\end{array}$ & Milk type & $\begin{array}{c}\text { Total } \\
\text { samples }\end{array}$ & $\begin{array}{l}\text { Number of } \\
\text { positive } \\
\text { samples }\end{array}$ & $\begin{array}{c}\% \\
\text { positive } \\
\text { sample }\end{array}$ & $\begin{array}{c}\text { Mycotoxin } \\
\text { concentration }\end{array}$ & Method of analysis & Reference \\
\hline \multirow{9}{*}{ OTA } & Italy & n.r. & 0 & 63 & 3 & 4.8 & 70 - 110 ng/L & LC-FLD & (Pattono et al., 2011) \\
\hline & Sweden & 1991 & $\mathrm{R}$ & 36 & 5 & 14 & $10-40 \mathrm{ng} / \mathrm{L}$ & IPC-FLD & $\begin{array}{l}\text { (Breitholtz-Emanuelsson, Olsen, } \\
\text { Oskarsson, Palminger \& Hult, 1993) }\end{array}$ \\
\hline & \multirow{2}{*}{ Norway } & $1997-98$ & 0 & 47 & 5 & 11 & $15-28 \mathrm{ng} / \mathrm{L}$ & \multirow{2}{*}{ LC-FLD } & \multirow[t]{2}{*}{ (Skaug, 1999) } \\
\hline & & $1995-96$ & $\mathrm{R}$ & 40 & 6 & 15 & $11-58 \mathrm{ng} / \mathrm{L}$ & & \\
\hline & France & 2003 & $\mathrm{R}$ & 264 & 3 & 1 & $5-6.6 \mathrm{ng} / \mathrm{L}$ & LC-FLD & $\begin{array}{c}\text { (Boudra, Barnouin, Dragacci \& Morgavi, } \\
\text { 2007) }\end{array}$ \\
\hline & Sudan & 2009 & $\mathrm{R}$ & 5 & 1 & 20 & $2730 \mathrm{ng} / \mathrm{L}$ & LC-UV & (Elzupir, Makawi \& Elhussein, 2009) \\
\hline & \multirow{3}{*}{ China } & \multirow{3}{*}{2012} & $\mathrm{R}$ & 30 & n.r & n.r & $56.7^{\text {a }} 84.1^{b} \mathrm{ng} / \mathrm{kg}$ & \multirow{3}{*}{ UHPLC-MS/MS } & \multirow{3}{*}{ (Huang et al., 2014) } \\
\hline & & & $\mathrm{D}$ & 8 & n.r & n.r & $27.0^{a} 49.4^{b} \mathrm{ng} / \mathrm{kg}$ & & \\
\hline & & & $\mathrm{L}$ & 12 & n.r & n.r & $26.8^{a} 57.9^{b} \mathrm{ng} / \mathrm{kg}$ & & \\
\hline AFB1 & \multirow{5}{*}{ Jordan } & \multirow{5}{*}{2007} & \multirow{5}{*}{$\begin{array}{l}R, R S, R G \\
P, P S, P G\end{array}$} & \multirow{5}{*}{60} & 5 & 8.3 & 2 270a ng/kg & \multirow{5}{*}{$\begin{array}{l}\text { LC-FLD } \\
\text { LC-UV }\end{array}$} & \multirow{5}{*}{ (Herzallah, 2009) } \\
\hline AFB2 & & & & & 5 & 8.3 & $210^{a} \mathrm{ng} / \mathrm{kg}$ & & \\
\hline AFG1 & & & & & 5 & 8.3 & $80^{a} \mathrm{ng} / \mathrm{kg}$ & & \\
\hline AFG2 & & & & & 5 & 8.3 & $90^{\mathrm{a}} \mathrm{ng} / \mathrm{kg}$ & & \\
\hline AFM2 & & & & & 5 & 8.3 & $<50^{a} \mathrm{ng} / \mathrm{kg}$ & & \\
\hline AFM2 & Japan & 2001-02 & $U$ & 52 & 25 & 48 & $0.9^{a} 3.4^{b} \mathrm{ng} / \mathrm{kg}$ & LC-FLD & (Nakajima et al., 2004) \\
\hline
\end{tabular}

a mean value, ${ }^{b}$ maximum value,$C=$ condensed cow milk, $D=$ powder cow milk,$P=$ pasteurized cow milk, $R=$ raw cow milk, $L=$ liquid cow milk, $O=$ organic $U=U H T$-treated, $n . r .=$ not

reported. $G C=$ gas chromatography, $L C=$ liquid chromatography, UHPLC $=$ ultra high pressure liquid chromatography, TLC $=$ thin layer chromatography, $F L D=$ fluorescence detector, UV-VIS

$=$ ultraviolet and visible detector, $\mathrm{MS} / \mathrm{MS}=$ tandem mass spectrometry, $\mathrm{QQQ}=$ triple quadrupole, $\mathrm{IPC}=$ ion-pair chromatography. 


\begin{tabular}{|c|c|c|c|c|c|c|c|c|c|c|}
\hline Milk origin & $\begin{array}{l}\text { Collection } \\
\text { year }\end{array}$ & $\begin{array}{l}\text { Milk } \\
\text { type }\end{array}$ & $\begin{array}{l}\text { Total } \\
\text { samples }\end{array}$ & $\begin{array}{l}\text { positive } \\
\text { samples }\end{array}$ & $\begin{array}{c}\% \\
\text { positive } \\
\text { sample } \\
\mathrm{s} \\
\end{array}$ & C.min-C.max & $\begin{array}{l}\text { samples } \\
>50 \mathrm{ng} / \mathrm{L}\end{array}$ & $\begin{array}{c}\% \\
>50 \mathrm{ng} / \mathrm{L}\end{array}$ & $\begin{array}{l}\text { Method of } \\
\text { analysis }\end{array}$ & Reference \\
\hline Albania & n.r. & $\mathrm{R}$ & 120 & n.r. & n.r. & $<50-850 \mathrm{ng} / \mathrm{kg}$ & 70 & 58.3 & TLC & (Panariti, 2001) \\
\hline Austria & 1999 & n.r. & 20 & 0 & 0 & $<10 \mathrm{ng} / \mathrm{kg}$ & 0 & 0 & n.r. & (EFSA, 2004b) \\
\hline Croatia & 2009 & $\mathrm{R}$ & 61 & n.r. & n.r. & $0.6-58.6 \mathrm{ng} / \mathrm{L}$ & 1 & 1.64 & ELISA & $\begin{array}{c}\text { (Bilandžić, Varenina \& Solomun, } \\
\text { 2010) }\end{array}$ \\
\hline Cyprus & 1992 & n.r. & 270 & 26 & 9.6 & $<10-50 \mathrm{ng} / \mathrm{kg}$ & 0 & 0 & n.r. & \multirow{5}{*}{ (EFSA, 2004b) } \\
\hline Finland & 1999 & n.r. & 296 & 1 & 0.3 & $<10-50 \mathrm{ng} / \mathrm{kg}$ & 0 & 0 & n.r. & \\
\hline France & 1999 & n.r. & 234 & 0 & 0 & $<30 \mathrm{ng} / \mathrm{kg}$ & 0 & 0 & n.r. & \\
\hline \multirow{2}{*}{ Germany } & 1999 & n.r. & 6537 & 211 & 3.2 & $<10-50 \mathrm{ng} / \mathrm{kg}$ & 0 & 0 & n.r. & \\
\hline & 2000 & n.r. & 3618 & 4 & 0.1 & $<10-50 \mathrm{ng} / \mathrm{kg}$ & 0 & 0 & n.r. & \\
\hline \multirow{12}{*}{ Greece } & $1995-1996$ & $\mathrm{P}$ & 81 & 72 & 88.9 & $0.5-177 \mathrm{ng} / \mathrm{L}$ & 3 & 3.7 & ELISA/LC-FLD & (Markaki \& Melissari, 1997) \\
\hline & $1999-2000$ & C & 15 & 14 & 93.3 & $5->50 \mathrm{ng} / \mathrm{L}$ & 2 & 13.3 & \multirow{10}{*}{ LC-FLD } & \multirow{10}{*}{$\begin{array}{c}\text { (Roussi, Govaris, Varagouli \& } \\
\text { Botsoglou, 2002) }\end{array}$} \\
\hline & $1999-2000$ & $\mathrm{P}$ & 82 & 70 & 85.4 & $5-50 \mathrm{ng} / \mathrm{L}$ & 0 & 0 & & \\
\hline & $1999-2000$ & $\mathrm{R}$ & 30 & 22 & 73.3 & $5->50 \mathrm{ng} / \mathrm{L}$ & 1 & 3.3 & & \\
\hline & $1999-2000$ & RG & 10 & 4 & 40 & $5-50 \mathrm{ng} / \mathrm{L}$ & 0 & 0 & & \\
\hline & $1999-2000$ & RS & 12 & 8 & 66.7 & $5-50 \mathrm{ng} / \mathrm{L}$ & 0 & 0 & & \\
\hline & $1999-2000$ & $U$ & 17 & 14 & 82.3 & $5-50 \mathrm{ng} / \mathrm{L}$ & 0 & 0 & & \\
\hline & $2000-2001$ & $\mathrm{P}$ & 54 & 43 & 79.6 & $5-50 \mathrm{ng} / \mathrm{L}$ & 0 & 0 & & \\
\hline & $2000-2001$ & $\mathrm{R}$ & 51 & 36 & 70.6 & $5->50 \mathrm{ng} / \mathrm{L}$ & 1 & 2 & & \\
\hline & $2000-2001$ & $R G$ & 12 & 8 & 66.7 & $5-50 \mathrm{ng} / \mathrm{L}$ & 0 & 0 & & \\
\hline & $2000-2001$ & RS & 15 & 11 & 73.3 & $5->50 \mathrm{ng} / \mathrm{L}$ & 1 & 6.7 & & \\
\hline & 2010 & $\mathrm{R}, \mathrm{O}, \mathrm{U}$ & 196 & 91 & 46.5 & $10 \mathrm{ng} / \mathrm{L}^{\mathrm{a}}$ & 2 & 1 & ELISA & $\begin{array}{c}\text { (Tsakiris, Tzatzarakis, Alegakis, } \\
\text { Vlachou, Renieri \& Tsatsakis, 2013) }\end{array}$ \\
\hline Ireland & 1999 & & 62 & 0 & 0 & $<20 \mathrm{ng} / \mathrm{kg}$ & 0 & 0 & n.r. & (EFSA, 2004b) \\
\hline
\end{tabular}

a mean value,$C=$ condensed cow milk, $O=$ organic cow milk, $P=$ pasteurized cow milk, $R=$ raw cow milk, RG= raw goat milk, $R S=$ raw sheep milk, $U=U H T$-treated cow milk, n.r. $=$ not reported. ELISA = Enzyme-Linked ImmunoSorbent Assay, LC = liquid chromatography, FLD = fluorescence detector, MS = mass spectrometry detector 
Table 3 (continued). Occurrence of Aflatoxin $\mathrm{ML}$ in animal milk samples in Europe

\begin{tabular}{|c|c|c|c|c|c|c|c|c|c|c|}
\hline Milk origin & $\begin{array}{l}\text { Collection } \\
\text { year }\end{array}$ & $\begin{array}{l}\text { Milk } \\
\text { type }\end{array}$ & $\begin{array}{c}\text { Total } \\
\text { samples }\end{array}$ & $\begin{array}{l}\text { positive } \\
\text { samples }\end{array}$ & $\begin{array}{c}\% \\
\text { positive } \\
\text { samples }\end{array}$ & C.min-C.max & $\begin{array}{l}\text { samples } \\
>\text { 50ng/L }\end{array}$ & $\begin{array}{c}\% \\
>50 \mathrm{ng} / \mathrm{L}\end{array}$ & $\begin{array}{l}\text { Method of } \\
\text { analysis }\end{array}$ & Reference \\
\hline \multirow{13}{*}{ Italy } & 1993 & $\mathrm{R}$ & 43 & 43 & 100 & $1-100 \mathrm{ng} / \mathrm{kg}$ & 14 & 32.5 & \multirow{4}{*}{ LC-FLD } & \multirow{4}{*}{ (Pietri, Bertuzzi, Moschini \& Piva, 2003) } \\
\hline & 1994 & $\mathrm{R}$ & 55 & 55 & 100 & $1-406 \mathrm{ng} / \mathrm{kg}$ & 9 & 16.3 & & \\
\hline & 1995 & $\mathrm{R}$ & 63 & 51 & 81 & $1-50 \mathrm{ng} / \mathrm{kg}$ & 0 & 0 & & \\
\hline & 1996 & $\mathrm{R}$ & 45 & 42 & 93.3 & $1-100 \mathrm{ng} / \mathrm{kg}$ & 1 & 2.2 & & \\
\hline & 1996 & $U$ & 161 & 125 & 78 & $<1-23.5 \mathrm{ng} / \mathrm{L}$ & 0 & 0 & LC-FLD & $\begin{array}{l}\text { (Galvano, Galofaro, Ritieni, Bognanno, } \\
\text { De Angelis \& Galvano, 2001) }\end{array}$ \\
\hline & 1998 & $\mathrm{R}$ & 66 & 66 & 100 & $1-397 \mathrm{ng} / \mathrm{kg}$ & 4 & 6 & LC-FLD & \multirow[t]{2}{*}{ (Pietri et al., 2003) } \\
\hline & 1999 & $\mathrm{R}$ & 60 & 60 & 100 & $1-50 \mathrm{ng} / \mathrm{kg}$ & 0 & 0 & LC-FLD & \\
\hline & 2000 & RS & 240 & 195 & 81 & $2-108 \mathrm{ng} / \mathrm{L}$ & 3 & 1.3 & LC-MS & (Bognanno et al., 2006) \\
\hline & $2003-2005$ & $P, R$ & 316 & n.r. & n.r. & $2-90 \mathrm{ng} / \mathrm{L}$ & 2 & 0.6 & LC-FLD & $\begin{array}{c}\text { (Nachtmann, Gallina, Rastelli, Ferro \& } \\
\text { Decastelli, 2007) }\end{array}$ \\
\hline & $2004-2005$ & $\mathrm{R}$ & 341 & 5 & 1.5 & until $50 \mathrm{ng} / \mathrm{L}$ & 3 & 1 & ELISA/LC & (Decastelli et al., 2007) \\
\hline & \multirow{3}{*}{2012} & $\mathrm{R}$ & 12 & 6 & 50 & $<3-10 \mathrm{ng} / \mathrm{L}$ & 0 & 0 & \multirow{3}{*}{ LC-FLD } & \multirow{3}{*}{ (Santini et al., 2013) } \\
\hline & & RG & 3 & 1 & 33.3 & $<3-5 \mathrm{ng} / \mathrm{L}$ & 0 & 0 & & \\
\hline & & RS & 34 & 20 & 58.8 & $<3-20 \mathrm{ng} / \mathrm{L}$ & 0 & 0 & & \\
\hline Netherlands & 1999 & n.r. & 30 & 5 & 16.7 & $10-50 \mathrm{ng} / \mathrm{kg}$ & 0 & 0 & n.r. & (EFSA, 2004b) \\
\hline \multirow{2}{*}{ Portugal } & 1999 & $\mathrm{R}$ & 31 & 25 & 80.6 & $5-50 \mathrm{ng} / \mathrm{kg}$ & 0 & 0 & n.r. & \multirow[t]{2}{*}{ (Martins \& Martins, 2000) } \\
\hline & 1999 & $U$ & 70 & 60 & 84.2 & $5-61 \mathrm{ng} / \mathrm{kg}$ & 2 & 2.9 & n.r. & \\
\hline Spain & 2000 & $\mathrm{R}$ & 92 & 5 & 5.4 & $14-24.9 \mathrm{ng} / \mathrm{L}$ & 0 & 0 & ELISA & (Rodriguez Velasco et al., 2003) \\
\hline Sweden & 1999 & n.r. & 11 & 0 & 0 & $<10 \mathrm{ng} / \mathrm{kg}$ & 0 & 0 & n.r. & (EFSA, 2004b) \\
\hline UK & 2001 & n.r. & 100 & 3 & 3 & $10-50 \mathrm{ng} / \mathrm{kg}$ & 0 & 0 & n.r. & (EFSA, 2004b) \\
\hline TOTAL & & & 13566 & & & & 119 & & & \\
\hline
\end{tabular}


Table 4. Occurrence of Aflatoxin Mn in animal milk samples in Africa

\begin{tabular}{|c|c|c|c|c|c|c|c|c|c|c|}
\hline Milk origin & $\begin{array}{l}\text { Collection } \\
\text { year }\end{array}$ & $\begin{array}{l}\text { Milk } \\
\text { type }\end{array}$ & $\begin{array}{c}\text { Total } \\
\text { samples }\end{array}$ & $\begin{array}{l}\text { positive } \\
\text { samples }\end{array}$ & $\begin{array}{c}\% \\
\text { positive } \\
\text { samples }\end{array}$ & C.min-C.max & $\begin{array}{l}\text { samples } \\
>50 \mathrm{ng} / \mathrm{L}\end{array}$ & $\begin{array}{c}\% \\
>50 \mathrm{ng} / \mathrm{L}\end{array}$ & $\begin{array}{l}\text { Method of } \\
\text { analysis }\end{array}$ & Reference \\
\hline \multirow{3}{*}{ Egypt } & $1999-2000$ & n.r. & 15 & 3 & 20 & $5000-8000 \mathrm{ng} / \mathrm{L}$ & $3^{a}$ & $20^{a}$ & \multirow{2}{*}{ LC-FLD } & \multirow{2}{*}{ (El-Sayed et al., 2000) } \\
\hline & $1999-\angle 000$ & $\mathrm{D}$ & 10 & n.r. & n.r. & $5000 \mathrm{ng} / \mathrm{L}$ & 1 & 10 & & \\
\hline & 2010 & $\mathrm{D}$ & 125 & 54 & 43.2 & $0.3-21.8 \mathrm{ng} / \mathrm{L}$ & 0 & 0 & ELISA & $\begin{array}{l}\text { (El-Tras, El-Kady \& Tayel, } \\
\text { 2011) }\end{array}$ \\
\hline Libya & 2002 & $\mathrm{R}$ & 49 & 35 & 71.4 & $30-2680 \mathrm{ng} / \mathrm{L}$ & 34 & 69.4 & LC-FLD & $\begin{array}{c}\text { (Elgerbi, Aidoo, Candlish \& } \\
\text { Tester, 2004) }\end{array}$ \\
\hline \multirow[t]{2}{*}{ Morocco } & 2006 & $P$ & 54 & 50 & 88.8 & $1-117 \mathrm{ng} / \mathrm{L}$ & 4 & 7.4 & LC-UV & $\begin{array}{c}\text { (Zinedine, González-Osnaya, } \\
\text { Soriano, Moltó, Idrissi \& } \\
\text { Mañes, 2007) }\end{array}$ \\
\hline & $2009-2010$ & $\mathrm{R}$ & 48 & 13 & 27 & $10-100 \mathrm{ng} / \mathrm{L}$ & 4 & 8 & LC-FLD & (El Marnissi et al., 2012) \\
\hline Nigeria & 2006 & $\mathrm{R}$ & 22 & $3^{b}$ & $13.6^{b}$ & $2040-4000 \mathrm{ng} / \mathrm{L}$ & $3 b$ & $13.6^{b}$ & TLC-2D & $\begin{array}{l}\text { (Atanda, Oguntubo, Adejumo, } \\
\text { Ikeorah \& Akpan, 2007) }\end{array}$ \\
\hline Kenya & 2006 & $P, U$ & 613 & 473 & 77.2 & $5-780 \mathrm{ng} / \mathrm{kg}$ & 162 & 26.4 & ELISA & (Kang'ethe \& Lang'a, 2009) \\
\hline Sudan & 2009 & $\mathrm{R}$ & 44 & 42 & 95.5 & $220-6900 \mathrm{ng} / \mathrm{L}$ & 42 & 95.5 & LC-FLD & (Elzupir \& Elhussein, 2010) \\
\hline TOTAL & & & 980 & & & & 253 & & & \\
\hline
\end{tabular}

a > $500 \mathrm{ng} / \mathrm{L},{ }^{\mathrm{b}}$ detection limit $=2000 \mathrm{ng} / \mathrm{L}, \mathrm{D}=$ powder cow milk, $\mathrm{P}=$ pasteurized cow milk, $\mathrm{R}=$ raw cow milk, $\mathrm{U}=\mathrm{UHT}$-treated cow milk, ELISA = Enzyme-Linked ImmunoSorbent Assay, LC = liquid chromatography, FLD = fluorescence detector, UV = ultraviolet detector, TLC-2D = Two-dimensional thin layer chromatography. 


\begin{tabular}{|c|c|c|c|c|c|c|c|c|c|c|}
\hline Milk origin & $\begin{array}{l}\text { Collection } \\
\text { year }\end{array}$ & $\begin{array}{l}\text { Milk } \\
\text { type }\end{array}$ & $\begin{array}{c}\text { Total } \\
\text { samples }\end{array}$ & $\begin{array}{l}\text { positive } \\
\text { samples }\end{array}$ & $\begin{array}{c}\% \\
\text { positive } \\
\text { samples }\end{array}$ & C.min-C.max & $\begin{array}{l}\text { samples } \\
>50 \mathrm{ng} / \mathrm{L}\end{array}$ & $\begin{array}{c}\% \\
>50 n g / L\end{array}$ & $\begin{array}{l}\text { Method of } \\
\text { analysis }\end{array}$ & Reference \\
\hline \multirow{9}{*}{ China } & 2012 & $R, L, D$ & 50 & n.r. & n.r. & $42.9^{b}-237.4 \mathrm{ng} / \mathrm{kg}$ & n.r. & n.r. & UHPLC-MS/MS & (Huang et al., 2014) \\
\hline & n.r. & n.r. & 50 & 3 & 6 & $10-250 \mathrm{ng} / \mathrm{kg}$ & $1 \mathrm{a}$ & n.r. & LC-MS/MS & $\begin{array}{c}\text { (H. Wang, Zhou, Liu, Yang \& } \\
\text { Guo, 2011) }\end{array}$ \\
\hline & n.r. & $P, U$ & 50 & 15 & 30 & $6-250 \mathrm{ng} / \mathrm{mL}$ & $1 \mathrm{a}$ & n.r. & LC-MS/MS & $\begin{array}{c}\text { (H. Wang, Zhou, Liu, Yang \& } \\
\text { Guo, 2010) }\end{array}$ \\
\hline & \multirow{2}{*}{ n.r. } & n.r. & 15 & 13 & 86.7 & $12.1-301.2 \mathrm{ng} / \mathrm{L}$ & 8 & 53.33 & \multirow{2}{*}{ LC-FLD } & \multirow{2}{*}{$\begin{array}{c}\text { (Guan, Li, Zhang, Zhang, } \\
\text { Zhang \& Jiang, 2011) }\end{array}$} \\
\hline & & $\mathrm{D}$ & 9 & 7 & 77.7 & $19.1-253.4 \mathrm{ng} / \mathrm{L}$ & 3 & 33.33 & & \\
\hline & \multirow{2}{*}{ n.r. } & DG & 3 & 1 & 33.3 & $118 \mathrm{ng} / \mathrm{kg}$ & 1 & 33.3 & \multirow{2}{*}{ LC-FLD } & \multirow{2}{*}{ (Y. Wang et al., 2012) } \\
\hline & & $R, P, U, D$ & 23 & 7 & 30.4 & $38-212 \mathrm{ng} / \mathrm{kg}$ & 6 & 26.1 & & \\
\hline & n.r. & n.r. & 27 & 21 & 77.78 & $13.3-1061.3 \mathrm{ng} / \mathrm{L}$ & 14 & 51.85 & ELISA & (Zhang et al., 2012) \\
\hline & $2006-2007$ & U & 233 & 112 & 48 & $\begin{array}{c}21.49^{b}-95.73 \\
n g / k g\end{array}$ & 48 & 20.6 & ELISA & (Guo, Yuan \& Yue, 2013) \\
\hline \multirow{4}{*}{ India } & \multirow{3}{*}{ n.r. } & DB & 10 & n.r. & n.r. & $>500-15000 \mathrm{ng} / \mathrm{L}$ & $5 a$ & 50 & \multirow{3}{*}{ ELISA } & \multirow{3}{*}{ (Thirumala-Devi et al., 2002) } \\
\hline & & PB & 44 & n.r. & n.r. & $>500-30000 \mathrm{ng} / \mathrm{L}$ & $16 a$ & 36 & & \\
\hline & & $\mathrm{RB}$ & 216 & n.r. & n.r. & $>500-48000 \mathrm{ng} / \mathrm{L}$ & $110 \mathrm{a}$ & 50.9 & & \\
\hline & n.r. & $P$ & 12 & 4 & 32 & $164 \mathrm{ng} / \mathrm{kg}$ & 3 & 33 & ELISA & $\begin{array}{c}\text { (Rastogi, Dwivedi, Khanna \& } \\
\text { Das, 2004) }\end{array}$ \\
\hline
\end{tabular}

a $>500 \mathrm{ng} / \mathrm{L}, \mathrm{b}$ mean value $\mathrm{n.r}$. $=$ not reported, $\mathrm{D}=$ powder cow milk, $\mathrm{DB}=$ powder buffalo milk, $\mathrm{DG}=$ powder goat milk, $\mathrm{P}=$ pasteurized cow milk, $\mathrm{PB}=$ pasteurized buffalo milk, $\mathrm{PG}=$ pasteurized goat milk, $P S=$ pasteurized sheep milk, $R=$ raw cow milk, $R B=$ raw buffalo milk, $R C=$ raw camel milk, $R G=$ raw goat milk, $R S=$ raw sheep milk, $U=U H T$-treated cow milk. ELISA $=$ EnzymeLinked ImmunoSorbent Assay, $L C=$ liquid chromatography, $F L D=$ fluorescence detector, MS/MS = tandem mass spectrometry, TLC = thin layer chromatography, $A C=$ affinity chromatography. 


\begin{tabular}{|c|c|c|c|c|c|c|c|c|c|c|}
\hline Milk origin & $\begin{array}{l}\text { Collection } \\
\text { year }\end{array}$ & $\begin{array}{l}\text { Milk } \\
\text { type }\end{array}$ & $\begin{array}{c}\text { Total } \\
\text { samples }\end{array}$ & $\begin{array}{l}\text { positive } \\
\text { samples }\end{array}$ & $\begin{array}{l}\text { \% positive } \\
\text { samples }\end{array}$ & C.min-C.max & $\begin{array}{l}\text { samples } \\
>50 \mathrm{ng} / \mathrm{L}\end{array}$ & $\begin{array}{c}\% \\
>50 \mathrm{ng} / \mathrm{L}\end{array}$ & $\begin{array}{l}\text { Method of } \\
\text { analysis }\end{array}$ & Reference \\
\hline \multirow{26}{*}{ Iran } & n.r. & $\mathrm{R}$ & 73 & 60 & 82.2 & n.r. & 60 & 82.2 & n.r. & (Tajik, Rohani \& Moradi, 2007) \\
\hline & 2001 & $\mathrm{R}$ & 111 & 85 & 76.6 & $15-280 \mathrm{ng} / \mathrm{L}$ & 44 & 40 & TLC & (Kamkar, 2005) \\
\hline & 2003 & $P$ & 624 & 624 & 100 & $<45->80 \mathrm{ng} / \mathrm{L}$ & 111 & 17.8 & ELISA & $\begin{array}{l}\text { (Alborzi, Pourabbas, Rashidi \& } \\
\text { Astaneh, 2006) }\end{array}$ \\
\hline & $2003-2004$ & $\mathrm{R}$ & 98 & 98 & 100 & $8-76 \mathrm{ng} / \mathrm{L}^{\mathrm{b}}$ & 37 & 37.7 & \multirow{2}{*}{ LC-FLD } & \multirow{2}{*}{ (Tajkarimi et al., 2007) } \\
\hline & 2004 & $\mathrm{R}$ & 319 & 172 & 54 & $57 \mathrm{ng} / \mathrm{L} \mathrm{b}$ & 73 & 23 & & \\
\hline & 2005 & $P$ & 128 & 128 & 100 & $31-113 \mathrm{ng} / \mathrm{kg}$ & 100 & 78 & ELISA & $\begin{array}{c}\text { (Oveisi, Jannat, Sadeghi, } \\
\text { Hajimahmoodi \& Nikzad, 2007) }\end{array}$ \\
\hline & \multirow{2}{*}{$2005-2006$} & $P$ & 72 & 72 & 100 & $5.1-28.5 \mathrm{ng} / \mathrm{L}$ & 0 & 0 & \multirow{2}{*}{ ELISA } & \multirow{2}{*}{ (Tajik et al., 2007) } \\
\hline & & $\mathrm{R}$ & 72 & 72 & 100 & $4.3-91.8 \mathrm{ng} / \mathrm{L}$ & 9 & 12.5 & & \\
\hline & 2006 & $P$ & 72 & 72 & 100 & $178.8-253.5 \mathrm{ng} / \mathrm{L}$ & 72 & 100 & ELISA & $\begin{array}{c}\text { (Sefidgar, Mirzae, Assmar \& Naddaf, } \\
\text { 2011) }\end{array}$ \\
\hline & 2006 & $\mathrm{R}$ & 120 & 120 & 100 & $4-352.3 \mathrm{ng} / \mathrm{L}$ & 68 & 56.7 & ELISA & $\begin{array}{c}\text { (Sefidgar, Azizi, Khosravi \& Roudbar- } \\
\text { Mohammadi, 2008) }\end{array}$ \\
\hline & 2006 & $\mathrm{R}, \mathrm{P}$ & 90 & 90 & 100 & $2.9-85 \mathrm{ng} / \mathrm{kg}$ & 30 & 33.3 & ELISA & (Nemati et al., 2010) \\
\hline & \multirow{2}{*}{2007} & $P$ & 40 & n.r. & n.r. & $23.2 \mathrm{ng} / \mathrm{L}^{\mathrm{b}}$ & n.r. & n.r. & \multirow{2}{*}{ ELISA } & \multirow{2}{*}{ (Mohamadi \& Alizadeh, 2010) } \\
\hline & & U & 40 & n.r. & n.r. & $19.5 \mathrm{ng} / \mathrm{L} \mathrm{b}$ & n.r. & n.r. & & \\
\hline & \multirow{6}{*}{$2007-2008$} & $\mathrm{R}$ & 75 & 59 & 78.7 & $60.1 \mathrm{ng} / \mathrm{L}^{\mathrm{b}}$ & 27 & 36 & \multirow{6}{*}{ ELISA } & \multirow{6}{*}{ (Rahimi et al., 2010) } \\
\hline & & RB & 75 & 29 & 38.7 & $31.9 \mathrm{ng} / \mathrm{L} b$ & 6 & 8 & & \\
\hline & & $\mathrm{RC}$ & 40 & 5 & 12.5 & $19 \mathrm{ng} / \mathrm{L}$ b & 0 & 0 & & \\
\hline & & RG & 60 & 19 & 31.7 & $30.1 \mathrm{ng} / \mathrm{L} b$ & 4 & 6.7 & & \\
\hline & & RS & 51 & 19 & 37.3 & $28.1 \mathrm{ng} / \mathrm{L}^{\mathrm{b}}$ & 2 & 3.9 & & \\
\hline & & $U$ & 210 & 116 & 55.2 & $8-249 \mathrm{ng} / \mathrm{L}$ & 70 & 33.3 & & \\
\hline & 2008 & $P$ & 196 & 196 & 100 & $19-126 \mathrm{ng} / \mathrm{L}$ & 158 & 80.6 & ELISA & $\begin{array}{c}\text { (Mohamadi Sani, Nikpooyan \& } \\
\text { Moshiri, 2010) }\end{array}$ \\
\hline & \multirow{2}{*}{$2008-2009$} & $P$ & 116 & 83 & 71.5 & $5.8-528.5 \mathrm{ng} / \mathrm{L}$ & 31 & 26.7 & \multirow{2}{*}{ ELISA } & \multirow{2}{*}{ (Fallah, 2010a) } \\
\hline & & U & 109 & 68 & 62.3 & $5.6-515.9 \mathrm{ng} / \mathrm{L}$ & 19 & 17.4 & & \\
\hline & 2009 & $P$ & 75 & 75 & 100 & 5 - >50 ng/kg & 3 & 4 & ELISA & $\begin{array}{l}\text { (Arast, Mohammadian \& } \\
\text { Behnamipour, 2012) }\end{array}$ \\
\hline & 2009 & $P$ & 91 & 66 & 72.5 & $13-250 \mathrm{ng} / \mathrm{L}$ & n.r. & n.r. & TLC & (Fallah, 2010b) \\
\hline & 2011 & $P$ & 60 & 60 & 100 & $2-64 \mathrm{ng} / \mathrm{L}$ & 1 & 1.6 & LC-FLD & (Sani \& Nikpooyan, 2012) \\
\hline & 2012 & $P$ & 45 & 45 & 100 & $8.8-64 \mathrm{ng} / \mathrm{L}$ & 13 & 28.9 & ELISA & (Riahi-Zanjani \& Balali-Mood, 2013) \\
\hline
\end{tabular}

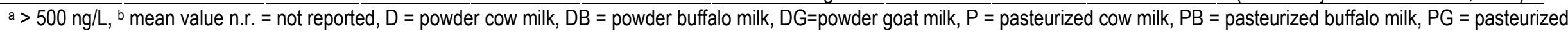
goat milk, $P S=$ pasteurized sheep milk, $R=$ raw cow milk, $R B=$ raw buffalo milk, $R C=$ raw camel milk, $R G=$ raw goat milk, $R S=$ raw sheep milk, $U=U H T$-treated cow milk. ELISA = EnzymeLinked ImmunoSorbent Assay, LC = liquid chromatography, FLD = fluorescence detector, MS/MS = tandem mass spectrometry, TLC = thin layer chromatography, $A C=$ affinity chromatography. 
Table 5 (continued). Occurrence of Aflatoxin $\mathrm{MZ}$ in animal milk samples in Asia

\begin{tabular}{|c|c|c|c|c|c|c|c|c|c|c|}
\hline Milk origin & $\begin{array}{c}\text { Collection } \\
\text { year }\end{array}$ & $\begin{array}{l}\text { Milk } \\
\text { type }\end{array}$ & $\begin{array}{c}\text { Total } \\
\text { samples }\end{array}$ & $\begin{array}{l}\text { positive } \\
\text { samples }\end{array}$ & $\begin{array}{c}\% \\
\text { positive } \\
\text { samples }\end{array}$ & C.min-C.max & $\begin{array}{l}\text { samples } \\
>50 \mathrm{ng} / \mathrm{L}\end{array}$ & $\begin{array}{c}\% \\
>50 \mathrm{ng} / \mathrm{L}\end{array}$ & $\begin{array}{l}\text { Method of } \\
\text { analysis }\end{array}$ & Reference \\
\hline \multirow[b]{2}{*}{ Japan } & $2001-2002$ & $\mathrm{U}$ & 208 & 207 & 99.5 & $1-29 \mathrm{ng} / \mathrm{kg}$ & 0 & 0 & LC-FLD & (Nakajima et al., 2004) \\
\hline & 2004 & $\mathrm{R}$ & 299 & n.r. & n.r. & $5-11 \mathrm{ng} / \mathrm{L}$ & 0 & 0 & LC-FLD & $\begin{array}{c}\text { (Sugiyama, Hiraoka \& Sugita- } \\
\text { Konishi, 2008) }\end{array}$ \\
\hline \multirow[t]{2}{*}{ Jordan } & 2007 & $\begin{array}{l}\text { R,RS, } \\
\text { RG, P, } \\
\text { PS, PG }\end{array}$ & 60 & 5 & 8.3 & $140 \mathrm{ng} / \mathrm{kg} \mathrm{b}^{\mathrm{b}}$ & n.r. & n.r. & $\begin{array}{c}\text { LC-FLD, } \\
\text { LC-UV }\end{array}$ & (Herzallah, 2009) \\
\hline & $2011-2012$ & $\mathrm{R}$ & 50 & 50 & 100 & $7.05-129.79 \mathrm{ng} / \mathrm{kg}$ & 21 & 42 & ELISA & (Omar, 2012) \\
\hline \multirow{2}{*}{ Korea } & \multirow{2}{*}{1997} & $\mathrm{D}$ & 24 & 18 & 75 & $26-342 \mathrm{ng} / \mathrm{L}$ & n.r. & n.r. & \multirow{2}{*}{ ELISA, LC-FLD } & \multirow{2}{*}{$\begin{array}{c}\text { (Kim, Shon, Ryu, Park, Hwang } \\
\text { \& Kim, 2000) }\end{array}$} \\
\hline & & $\mathrm{P}$ & 70 & 53 & 75.7 & $2-52 \mathrm{ng} / \mathrm{L}$ & n.r. & n.r. & & \\
\hline Kuwait & 1998 & $\mathrm{P}$ & 25 & 13 & 58 & $10-210 \mathrm{ng} / \mathrm{L}$ & 6 & 24 & LC-FLD & (Srivastava et al., 2001) \\
\hline \multirow{6}{*}{ Lebanon } & \multirow{6}{*}{ n.r. } & $\mathrm{P}$ & 60 & n.r. & n.r. & $11.88-26.33 n g / L$ & 0 & 0 & \multirow{6}{*}{ ELISA } & \multirow{6}{*}{ (Hassan \& Kassaify, 2014) } \\
\hline & & $P G$ & 4 & n.r. & n.r. & $4.55 \mathrm{ng} / \mathrm{L}^{\mathrm{b}}$ & 0 & 0 & & \\
\hline & & PS & 4 & n.r. & n.r. & $2.1 \mathrm{ng} / \mathrm{Lb}^{\mathrm{b}}$ & 0 & 0 & & \\
\hline & & $\mathrm{R}$ & 60 & n.r. & n.r. & $13.89-35.60 \mathrm{ng} / \mathrm{L}$ & 0 & 0 & & \\
\hline & & RG & 4 & n.r. & n.r. & $6.85 \mathrm{ng} / \mathrm{L}^{\mathrm{b}}$ & 0 & 0 & & \\
\hline & & RS & 4 & n.r. & n.r. & $3.33 \mathrm{ng} / \mathrm{L} \mathrm{b}$ & 0 & 0 & & \\
\hline
\end{tabular}

a $>500 \mathrm{ng} / \mathrm{L}, \mathrm{b}$ mean value $\mathrm{n.r}$. $=$ not reported, $\mathrm{D}=$ powder cow milk, $\mathrm{DB}=$ powder buffalo milk, $\mathrm{DG}=$ powder goat milk, $\mathrm{P}=$ pasteurized cow milk, $P B=$ pasteurized buffalo milk, $P G=$ pasteurized goat milk, $P S=$ pasteurized sheep milk, $R=$ raw cow milk, $R B=$ raw buffalo milk, $R C=$ raw camel milk, $R G=$ raw goat milk, $R S=$ raw sheep milk, $U=U H T$-treated cow milk. ELISA = EnzymeLinked ImmunoSorbent Assay, LC = liquid chromatography, FLD = fluorescence detector, MS/MS = tandem mass spectrometry, TLC = thin layer chromatography, $A C=$ affinity chromatography . 
Table 5 (continued). Occurrence of Aflatoxin MZ in animal milk samples in Asia

\begin{tabular}{|c|c|c|c|c|c|c|c|c|c|c|}
\hline Milk origin & $\begin{array}{l}\text { Collection } \\
\text { year }\end{array}$ & $\begin{array}{l}\text { Milk } \\
\text { type }\end{array}$ & $\begin{array}{c}\text { Total } \\
\text { samples }\end{array}$ & $\begin{array}{l}\text { positive } \\
\text { samples }\end{array}$ & $\begin{array}{c}\% \\
\text { positive } \\
\text { samples } \\
\end{array}$ & C.min-C.max & $\begin{array}{l}\text { samples } \\
\text { >50ng/L }\end{array}$ & $\begin{array}{c}\% \\
>50 \mathrm{ng} / \mathrm{L}\end{array}$ & $\begin{array}{l}\text { Method of } \\
\text { analysis }\end{array}$ & Reference \\
\hline \multirow{6}{*}{ Pakistan } & 2005 & $\mathrm{R}$ & 168 & 167 & 99.4 & $10-700 \mathrm{ng} / \mathrm{L}$ & 167 & 99.4 & AC-FLD & \multirow{3}{*}{ (Hussain \& Anwar, 2008) } \\
\hline & 2007 & $\mathrm{R}$ & 120 & 63 & 52.5 & $4-87^{b} \mathrm{ng} / \mathrm{L}$ & n.r. & n.r. & \multirow{2}{*}{ LC-FLD } & \\
\hline & 2007 & $\mathrm{RB}$ & 360 & 153 & 42.5 & $4-75^{b} \mathrm{ng} / \mathrm{L}$ & n.r. & n.r. & & \\
\hline & n.r. & $\mathrm{R}$ & 21 & 18 & 85.7 & $14-40 \mathrm{ng} / \mathrm{L}$ & 0 & 0 & ELISA & $\begin{array}{c}\text { (Maqbool, Anwar-Ul-Haq \& Ahmad, } \\
\text { 2009) }\end{array}$ \\
\hline & 2012 & $\mathrm{R}$ & 104 & 39 & 37.5 & $4-890 \mathrm{ng} / \mathrm{L}$ & 26 & 25 & & \\
\hline & 2012 & U & 84 & 35 & 41.7 & $4-510 \mathrm{ng} / \mathrm{L}$ & 20 & 23.8 & LC-FLU & (Iqbal et al., 2013) \\
\hline \multirow{5}{*}{ Syria } & \multirow{5}{*}{$2005-2006$} & $\mathrm{D}$ & 8 & 1 & 1 & $12 \mathrm{ng} / \mathrm{L}$ & 0 & 0 & \multirow{5}{*}{ ELISA } & \multirow{5}{*}{ (Ghanem \& Orfi, 2009) } \\
\hline & & $P$ & 10 & 10 & 100 & $8-765 \mathrm{ng} / \mathrm{L}$ & 8 & 80 & & \\
\hline & & $\mathrm{R}$ & 74 & 70 & 95 & $20-690 \mathrm{ng} / \mathrm{L}$ & 41 & 59 & & \\
\hline & & RG & 11 & 7 & 64 & $8-54 \mathrm{ng} / \mathrm{L}$ & 1 & 14 & & \\
\hline & & RS & 23 & 13 & 57 & $6-634 \mathrm{ng} / \mathrm{L}$ & 3 & 23 & & \\
\hline Thailand & $2006-2007$ & $\mathrm{R}$ & 240 & 240 & 100 & $14-197 \mathrm{ng} / \mathrm{L}$ & 167 & 70 & LC-FLD & (Ruangwises \& Ruangwises, 2010) \\
\hline \multirow{7}{*}{ Turkey } & 2004 & $U$ & 50 & 50 & 100 & $5-244 \mathrm{ng} / \mathrm{L}$ & 10 & 20 & ELISA & (Gundinc \& Filazi, 2009) \\
\hline & 2005 & U & 129 & 75 & 58.1 & $10-543.64 \mathrm{ng} / \mathrm{L}$ & 61 & 47 & ELISA & (Unusan, 2006) \\
\hline & & $\mathrm{U}$ & 24 & 14 & 58.3 & $<10-50.5 \mathrm{ng} / \mathrm{L}$ & 1 & 3.7 & \multirow{2}{*}{ LC-FLD } & \multirow{2}{*}{ (Gurbay et al., 2010) } \\
\hline & n.r. & $\mathrm{P}$ & 3 & 2 & 66.7 & $<10-50 \mathrm{ng} / \mathrm{L}$ & 0 & 0 & & \\
\hline & $2006-2007$ & $U$ & 150 & 89 & 59 & $<5->100 \mathrm{ng} / \mathrm{kg}$ & 16 & 10.7 & ELISA & $\begin{array}{c}\text { (Aydemir Atasever, Adiguzel, } \\
\text { Atasever, Ozlu \& Ozturan, 2010) }\end{array}$ \\
\hline & 2010 & $\mathrm{R}$ & 36 & 22 & 61.1 & $1-10 \mathrm{ng} / \mathrm{kg}$ & 0 & 0 & ELISA & $\begin{array}{c}\text { (Aksoy, Yavuz, Guvenc, Das, Terzi } \\
\text { \& Celik, 2010) }\end{array}$ \\
\hline & n.r. & $\mathrm{R}$ & 135 & 60 & 44.4 & $5-68.3 \mathrm{ng} / \mathrm{L}$ & n.r. & n.r. & ELISA & (Ozsunar et al., 2010) \\
\hline
\end{tabular}

a $>500$ ng/L, ${ }^{b}$ mean value $n . r .=$ not reported, $D=$ powder cow milk, $D B=$ powder buffalo milk, $D G=$ powder goat milk, $P=$ pasteurized cow milk, $P B=$ pasteurized buffalo milk, $P G=$ pasteurized goat milk, $P S=$ pasteurized sheep milk, $R=$ raw cow milk, $R B=$ raw buffalo milk, $R C=$ raw camel milk, $R G=$ raw goat milk, $R S=$ raw sheep milk, $U=U H T-$ treated cow milk. ELISA = EnzymeLinked ImmunoSorbent Assay, LC = liquid chromatography, $F L D=$ fluorescence detector, $M S / M S=$ tandem mass spectrometry, TLC = thin layer chromatography, $A C=$ affinity chromatography. 
Table 6. Occurrence of Aflatoxin Mn in animal milk samples in America

\begin{tabular}{|c|c|c|c|c|c|c|c|c|c|c|}
\hline Milk origin & $\begin{array}{l}\text { Collection } \\
\text { year }\end{array}$ & Milk type & $\begin{array}{l}\text { Total } \\
\text { sample } \\
\text { s }\end{array}$ & $\begin{array}{l}\text { positive } \\
\text { samples }\end{array}$ & $\begin{array}{c}\% \\
\text { positive } \\
\text { samples }\end{array}$ & C.min-C.max & $\begin{array}{l}\text { samples } \\
>50 \mathrm{ng} / \mathrm{L}\end{array}$ & $\begin{array}{c}\% \\
>50 \mathrm{ng} / \mathrm{L}\end{array}$ & $\begin{array}{l}\text { Method of } \\
\text { analysis }\end{array}$ & Reference \\
\hline \multirow{4}{*}{ Argentina } & \multirow{3}{*}{1999} & $D$ & 5 & 4 & 80 & $10-14 \mathrm{ng} / \mathrm{L}$ & 0 & 0 & \multirow{3}{*}{ ELISA } & \multirow{3}{*}{$\begin{array}{c}\text { (López, Ramos, Ramadán \& } \\
\text { Bulacio, 2003) }\end{array}$} \\
\hline & & $P$ & 16 & 8 & 50 & $10-17 \mathrm{ng} / \mathrm{L}$ & 0 & 0 & & \\
\hline & & $\mathrm{R}$ & 56 & 6 & 10.7 & 12 - $30 \mathrm{ng} / \mathrm{L}$ & 0 & 0 & & \\
\hline & 2007 & $\mathrm{R}$ & 94 & 60 & 64 & $10-70 \mathrm{ng} / \mathrm{L}$ & 10 & 11 & LC-MS/MS & $\begin{array}{l}\text { (Alonso, Monge, Larriestra, } \\
\text { Dalcero, Cavaglieri \& } \\
\text { Chiacchiera, 2010) }\end{array}$ \\
\hline \multirow{10}{*}{ Brazil } & 1992 & $\mathrm{P}$ & 52 & 4 & 7.7 & 70- $370 \mathrm{ng} / \mathrm{L}$ & 4 & 7.7 & LC-FLD & $\begin{array}{c}\text { (De Sylos, Rodriguez-Amaya \& } \\
\text { Carvalho, 1996) }\end{array}$ \\
\hline & n.r. & $\mathrm{D}$ & 300 & 33 & 11 & $100-1000 \mathrm{ng} / \mathrm{L}$ & 33 & 11 & ELISA & (Oliveira et al., 1997) \\
\hline & \multirow{2}{*}{$1999-2000$} & $P$ & 79 & 58 & 73.4 & $15-500 \mathrm{ng} / \mathrm{L}$ & 12 & 15.2 & \multirow{2}{*}{ LC-FLD } & \multirow{2}{*}{$\begin{array}{l}\text { (Garrido, Iha, Santos Ortolani \& } \\
\text { Duarte Favaro, 2003) }\end{array}$} \\
\hline & & U & 60 & 53 & 88.3 & $15-500$ ng/L & 17 & 28.3 & & \\
\hline & \multirow{3}{*}{$2004-2005$} & DG & 12 & 8 & 66.7 & $<10-100 \mathrm{ng} / \mathrm{L}$ & 4 & 33.3 & \multirow{3}{*}{ LC-FLD } & \multirow{3}{*}{ (Oliveira \& Ferraz, 2007) } \\
\hline & & $P G$ & 12 & 7 & 58.3 & $<10-200 \mathrm{ng} / \mathrm{L}$ & 3 & 25 & & \\
\hline & & UG & 12 & 10 & 83.3 & $<10-200 \mathrm{ng} / \mathrm{L}$ & 6 & 50 & & \\
\hline & \multirow{3}{*}{ n.r. } & $\mathrm{D}$ & 12 & 12 & 100 & $20-760 \mathrm{ng} / \mathrm{L}$ & $1 \mathrm{a}$ & n.r. & \multirow{3}{*}{ LC-FLD } & \multirow{3}{*}{ (Iha et al., 2013) } \\
\hline & & $P$ & 47 & 39 & 83 & $9-437 \mathrm{ng} / \mathrm{L}$ & $1^{a}$ & n.r. & & \\
\hline & & U & 17 & 13 & 76.5 & $8-215 \mathrm{ng} / \mathrm{L}$ & 1 a & n.r. & & \\
\hline \multirow{2}{*}{ Colombia } & 2004 & $P$ & 120 & 83 & 69.2 & $10.7-213 \mathrm{ng} / \mathrm{L}$ & $1^{a}$ & n.r. & \multirow{2}{*}{ LC-FLD } & \multirow{2}{*}{ (Diaz \& Espitia, 2006) } \\
\hline & 2005 & $\mathrm{P}$ & 121 & 96 & 79.3 & $10.6-288.9 \mathrm{ng} / \mathrm{L}$ & 1 a & n.r. & & \\
\hline Mexico & n.r. & $\mathrm{R}$ & 40 & 32 & 80 & $6-65 \mathrm{ng} / \mathrm{L}$ & $1^{a}$ & n.r. & ELISA & $\begin{array}{l}\text { (Reyes Velázquez, Patricio } \\
\text { Martínez, Isaías Espinosa, Nathal } \\
\text { Vera, De Lucas Palacios \& Rojo, } \\
\text { 2009) }\end{array}$ \\
\hline \multirow{2}{*}{ Trinidad } & \multirow{2}{*}{ n.r. } & $P$ & 37 & $0^{a}$ & $0^{a}$ & $500 \mathrm{ng} / \mathrm{L}$ & n.r. ${ }^{a}$ & n.r. ${ }^{a}$ & \multirow{2}{*}{ RIA } & \multirow{2}{*}{ (Offiah \& Adesiyun, 2007) } \\
\hline & & $\mathrm{R}$ & 175 & $13^{a}$ & $7.4^{a}$ & $500 \mathrm{ng} / \mathrm{L}$ & $13^{a}$ & $7.4^{a}$ & & \\
\hline TOTAL & & & 1267 & & & & 109 & & & \\
\hline
\end{tabular}

a $>500 \mathrm{ng} / \mathrm{L}, \mathrm{n} . \mathrm{r} .=$ not reported, $\mathrm{D}=$ powder cow milk, $\mathrm{DG}=$ powder goat milk, $\mathrm{P}=$ pasteurized cow milk, $\mathrm{PG}=$ pasteurized goat milk, $\mathrm{R}=$ raw cow milk, $\mathrm{U}=\mathrm{UHT}$-treated cow milk, UG = UHTtreated goat milk, ELISA = Enzyme-Linked ImmunoSorbent Assay, LC = liquid chromatography, FLD = fluorescence detector, MS/MS = tandem mass spectrometry, RIA = Radioimmunoassay. 